\title{
Inhibition of Fast Nerve Conduction Produced by Analgesics and Analgesic Adjuvants-Possible Involvement in Pain Alleviation
}

\author{
Eiichi Kumamoto \\ Department of Physiology, Saga Medical School, 5-1-1 Nabeshima, Saga 849-8501, Japan; \\ kumamote@cc.saga-u.ac.jp
}

Received: 23 February 2020; Accepted: 1 April 2020; Published: 5 April 2020

check for updates

\begin{abstract}
Nociceptive information is transmitted from the periphery to the cerebral cortex mainly by action potential (AP) conduction in nerve fibers and chemical transmission at synapses. Although this nociceptive transmission is largely inhibited at synapses by analgesics and their adjuvants, it is possible that the antinociceptive drugs inhibit nerve AP conduction, contributing to their antinociceptive effects. Many of the drugs are reported to inhibit the nerve conduction of AP and voltage-gated $\mathrm{Na}^{+}$and $\mathrm{K}^{+}$channels involved in its production. Compound action potential (CAP) is a useful measure to know whether drugs act on nerve AP conduction. Clinically-used analgesics and analgesic adjuvants (opioids, non-steroidal anti-inflammatory drugs, $\alpha_{2}$-adrenoceptor agonists, antiepileptics, antidepressants and local anesthetics) were found to inhibit fast-conducting CAPs recorded from the frog sciatic nerve by using the air-gap method. Similar actions were produced by antinociceptive plant-derived chemicals. Their inhibitory actions depended on the concentrations and chemical structures of the drugs. This review article will mention the inhibitory actions of the antinociceptive compounds on CAPs in frog and mammalian peripheral (particularly, sciatic) nerves and on voltage-gated $\mathrm{Na}^{+}$and $\mathrm{K}^{+}$channels involved in AP production. Nerve AP conduction inhibition produced by analgesics and analgesic adjuvants is suggested to contribute to at least a part of their antinociceptive effects.
\end{abstract}

Keywords: analgesic; analgesic adjuvant; antinociception; nerve conduction; sciatic nerve; compound action potential; $\mathrm{Na}^{+}$channel; $\mathrm{K}^{+}$channel

\section{Introduction}

Nociceptive information from the periphery to the cerebral cortex is mainly transmitted by action potential (AP) conduction in nerve fibers and chemical transmission at synapses (see [1,2] for reviews). Nociceptive pain is usually acute and relieved by narcotic analgesics such as opioids and antipyretic analgesics including non-steroidal anti-inflammatory drugs (NSAIDs). On the other hand, pain may persist or recur for longer than three months, which is called chronic pain. One type of chronic pain, neuropathic pain, which occurs as a result of damage to the peripheral or central nervous system (PNS and CNS, respectively), is characterized by a hyper-excitability of neurons near the injured neuronal tissues (see [3] for review). This type of pain is often resistant to analgesics such as opioids and NSAIDs and is thus treated by using analgesic adjuvants such as $\alpha_{2}$-adrenoceptor agonists, antiepileptics, antidepressants and local anesthetics (see [4-11] for reviews). Although the main target of analgesics and analgesic adjuvants, except for NSAIDs and local anesthetics, is generally synapses (see [12-14] for reviews), it is possible that all of their drugs inhibit nerve AP conduction, partly contributing to their inhibitory effects on pain.

The AP conduction is mediated by voltage-gated $\mathrm{Na}^{+}$and $\mathrm{K}^{+}$channels located in nerve fibers. Thus, a depolarizing stimulus given to a nerve fiber point activates $\mathrm{Na}^{+}$channels expressed in membranes of 
the fiber, allowing $\mathrm{Na}^{+}$entry to the cytoplasm, caused by the gradient of the electrochemical potential of $\mathrm{Na}^{+}$, leading to a self-regenerative production of AP. This in turn results in an outward current (membrane depolarization) in a fiber point adjacent to the point to produce opening of other $\mathrm{Na}^{+}$ channels and so forth. Such a production of AP subsides by a subsequent inactivation of $\mathrm{Na}^{+}$channels and activation of $\mathrm{K}^{+}$channels (see $[15,16]$ for reviews).

In a bundle of nerve fibers exposed to insulator such as oil, sucrose or air, AP conduction in each fiber produces AP current flowing through nerve bundle surface having high resistance that can be measured as a potential difference, i.e., compound action potential (CAP), by using two electrodes put on the nerve. Sciatic nerve trunk dissected from frogs is a useful preparation to easily and stably record voltage-gated $\mathrm{Na}^{+}$-channel blocker tetrodotoxin (TTX)-sensitive and fast-conducting (possibly myelinated $\mathrm{A} \alpha$-fiber mediated) CAPs by using the nerve trunk exposed to air (air-gap method). A voltage-gated delayed-rectifier $\mathrm{K}^{+}$-channel inhibitor tetraethylammonium increased the half-peak duration of the CAP with no change in its peak amplitude, indicating an involvement of $\mathrm{K}^{+}$channels (see [17] for review). Although not only fast-conducting but also slow-conducting (C-fiber mediated) CAPs were recorded from the frog sciatic nerve, the latter had much smaller peak amplitude and conduction velocity than the former [18].

Frog sciatic nerve fast-conducting CAPs were found to be inhibited by clinically-used antinociceptive drugs such as many kinds of opioids including tramadol [19,20], NSAIDs [21], an $\alpha_{2}$-adrenoceptor agonist dexmedetomidine ((+)-(S)-4-[1-(2,3-dimethylphenyl)-ethyl]-1H-imidazole or DEX [22]), antiepileptics [23], antidepressants [24] and many kinds of local anesthetics (lidocaine, ropivacaine, prilocaine, levobupivacaine, bupivacaine, cocaine, procaine, benzocaine, tetracaine and pramoxine [19,20,23,25-27]) and also by a general anesthetic propofol [25]. These inhibitory actions were concentration-dependent and depended on the chemical structures of the drugs. This review article will mention the effects of the analgesics and analgesic adjuvants on CAPs recorded from the frog sciatic nerve and discuss a difference in nerve AP conduction inhibition among the drugs. For comparison, it will be described how the antinociceptive drugs affect mammalian peripheral nerve CAPs and voltage-gated $\mathrm{Na}^{+}$and $\mathrm{K}^{+}$channels involved in the production of AP, when data are available. Moreover, it will be shown that antinociceptive plant-derived compounds also inhibit frog sciatic nerve CAPs with efficacies comparable to those of NSAIDs and analgesic adjuvants.

\section{Actions of Analgesics on Nerve Conduction}

\subsection{Opioids}

Opioids are well-known to inhibit glutamatergic excitatory transmission by activating opioid receptors in the CNS including the central terminals of primary-afferent fibers, resulting in antinociception ([28-30]; see [31,32] for reviews). Not only central but also peripheral terminal opioid receptors in primary-afferent neurons are thought to be involved in antinociception ([33-36]; see [37] for review). Opioids also exhibit a local anesthetic effect in the PNS. Although it has been reported in decerebrated cats that the perineural administration of an opioid morphine has no effect on CAPs in the superficial radial nerve [38], AP conduction in peripheral nerve fibers is generally blocked by opioids. For example, opioids such as fentanyl and sufentanil decreased the peak amplitudes of CAPs recorded from peripheral nerve fibers [39] and inhibited peripheral nerve AP conduction [40].

A morphine-induced CAP inhibition in mammalian peripheral nerve fibers was antagonized by a non-specific opioid-receptor antagonist naloxone, indicating an involvement of opioid receptors [41]. Consistent with this observation, binding and immunohistochemical studies have shown the localization of opioid receptors in mammalian peripheral nerve fibers [42-44]. It has been also demonstrated that a frog sciatic nerve CAP inhibition produced by opioids is sensitive to naloxone [45]. On the contrary, there are reports showing that opioids decrease CAP peak amplitudes [39] and suppress nerve AP conduction [40] in a manner resistant to naloxone. 


\subsubsection{Tramadol}

The compound (1RS,2RS)-2-[(dimethylamino)methyl]-1-(3-methoxyphenyl)cyclohexanol hydrochloride (tramadol) is an orally-active opioid which is clinically used as an analgesic in the CNS [46]. Although tramadol is metabolized to various compounds such as mono-O-desmethyltramadol (M1) via $\mathrm{N}$ - and $\mathrm{O}$-demethylation in animals and humans [47], M1 is a therapeutically active drug as a central analgesic [46]. One of cellular mechanisms for the antinociceptive effect of tramadol is the activation of $\mu$-opioid receptors [48,49]. In agreement with this idea, M1 has the highest affinity for cloned $\mu$-opioid receptors among the metabolites of tramadol. M1 is reported to inhibit glutamatergic excitatory transmission in spinal lamina II (substantia gelatinosa) neurons which play a crucial role in regulating nociceptive transmission to the spinal dorsal horn from the periphery, resulting in a decrease in the excitability of the neurons [50-52]. In addition to such a central activity, tramadol is known to have a local anesthetic effect following its intradermal injection in patients ([53-55]; see [56] for review). Consistent with this result, in vivo studies have shown a spinal somatosensory evoked potential inhibition produced by a direct application of tramadol to the rat sciatic nerve [57].

Tramadol reduced the peak amplitude of CAPs recorded from the frog sciatic nerve in a concentration-dependent manner in a range of 0.2 to $5 \mathrm{mM}$ [19]. A similar CAP inhibitory action of tramadol has been reported by other investigators in the frog [58] and rat sciatic nerve $[59,60]$. Analysis based on the Hill equation demonstrated that half-maximal inhibitory concentration $\left(\mathrm{IC}_{50}\right)$ value for tramadol to reduce frog sciatic nerve CAP amplitudes is $2.3 \mathrm{mM}$; this $\mathrm{IC}_{50}$ value was smaller by about three-fold than that $(6.6 \mathrm{mM})$ reported previously for the frog sciatic nerve [58]. Rat sciatic nerve CAPs were inhibited by tramadol ( $37 \%$ peak amplitude reduction at $4 \mathrm{mM}$ ) less effectively than frog sciatic nerve's ones [59]. This inhibitory action of tramadol in the frog sciatic nerve was not affected by the pretreatment of the sciatic nerve with naloxone $(0.01 \mathrm{mM})$; a $\mu$-opioid receptor agonist (D-Ala ${ }^{2}, N-\mathrm{Me}^{-} \mathrm{Phe}^{4}, \mathrm{Gly}^{5}$-ol)enkephalin (DAMGO; $1 \mu \mathrm{M}$ ) had no effect on frog sciatic nerve CAPs. Furthermore, CAPs were affected by much smaller extents by M1 (see below) that is similar in chemical structure to tramadol while exhibiting a higher affinity for $\mu$-opioid receptors than tramadol [61]. These results indicate that the tramadol-induced CAP inhibition is not mediated by opioid receptors [19]. Consistent with this result, a spinal somatosensory evoked potential inhibition following the application of tramadol on rat sciatic nerves in vivo was resistant to naloxone [57]. Although tramadol inhibits noradrenaline (NA) and serotonin (5-hydroxytryptamine; 5-HT) reuptake at concentrations similar to those that activate $\mu$-opioid receptors [62,63], a combination of inhibitors of the reuptake of NA and 5-HT (desipramine and fluoxetine, respectively; each $10 \mu \mathrm{M}$; see Section 3.3) did not affect frog sciatic nerve CAPs, indicating no involvement of NA and 5-HT reuptake inhibition in the CAP inhibition [19].

The CAP inhibition produced by tramadol is possibly due to an inhibition of voltage-gated $\mathrm{Na}^{+}$ and $\mathrm{K}^{+}$channels involved in the production of AP. Tramadol concentration-dependently reduced the peak amplitude of TTX-sensitive $\mathrm{Na}^{+}$channel currents recorded from dorsal root ganglion (DRG) neuroblastoma hybridoma cell line ND7/23 cells with an $\mathrm{IC}_{50}$ value of $0.194 \mathrm{mM}$ [64] and from HEK293 cells expressing rat Nav1.2 channels with an $\mathrm{IC}_{50}$ value of $0.103 \mathrm{mM}$ [65]. These values were smaller than that $(2.3 \mathrm{mM})$ for frog sciatic nerve CAP inhibition. It has been demonstrated that tramadol suppresses the current amplitude of delayed rectifier $\mathrm{K}^{+}$-channels (Kv3.1a type) expressed in NG 108-15 cells with an $\mathrm{IC}_{50}$ of $0.025 \mathrm{mM}$, a value much less than $2.3 \mathrm{mM}$ [66]. Such $\mathrm{IC}_{50}$ values for tramadol to inhibit CAPs, $\mathrm{Na}^{+}$and $\mathrm{K}^{+}$channels were higher than its clinically relevant concentration of about $2 \mu \mathrm{M}$ in serum [52,67].

Unlike tramadol, M1 (1-2 mM) did not affect frog sciatic nerve CAPs. This was confirmed in the frog sciatic nerve whose CAPs were inhibited by tramadol (1 mM; [19]). CAP peak amplitudes were reduced by $9 \%$ by $\mathrm{M} 1$ at $5 \mathrm{mM}$. Consistent with such smaller effects of M1, APs conducting on rat primary-afferent fibers were not blocked when the effect of M1 $(1 \mathrm{mM})$ on dorsal root-evoked excitatory postsynaptic currents was examined by applying the patch-clamp technique to lamina II neurons in spinal cord slices [51]. It is interesting to note that tramadol has $-\mathrm{OCH}_{3}$ bound to the benzene ring 
while $\mathrm{M} 1$ has $-\mathrm{OH}$ and thus that the methyl group is present in tramadol but not M1. This result indicates that the difference in chemical structure between tramadol and M1 is responsible for the distinction in CAP inhibition (see Figure 5a in [19] for a comparison of the chemical structures of the two compounds).

\subsubsection{Other Opioids}

In order to reveal whether such a structure-activity relationship is seen for other opioids, the effects of morphine, codeine and ethylmorphine on frog sciatic nerve CAPs were examined. Morphine concentration-dependently reduced CAP peak amplitude; this extent at $5 \mathrm{mM}$ was $15 \%$. Codeine, which has $-\mathrm{OCH}_{3}$ in place of $-\mathrm{OH}$ in morphine, at $5 \mathrm{mM}$ reduced CAP peak amplitude by $30 \%$. Moreover, $\mathrm{CAPs}$ were more effectively inhibited by ethylmorphine, where -OH of morphine is replaced by $-\mathrm{OCH}_{2} \mathrm{CH}_{3}$; amplitude reduction at $5 \mathrm{mM}$ was $61 \%$. IC 50 value for ethylmorphine in reducing CAP peak amplitudes was $4.6 \mathrm{mM}$. CAP inhibitions produced by morphine $(10 \mathrm{mM})$, codeine $(5 \mathrm{mM})$ and ethylmorphine $(2 \mathrm{mM})$ were resistant to naloxone $(0.01 \mathrm{mM})$. Naloxone at a high concentration such as $1 \mathrm{mM}$ by itself reduced by $9 \%$ CAP peak amplitudes, but did not affect morphine $(10 \mathrm{mM})$ activity [20]. These results indicate no involvement of opioid receptors in the CAP inhibition produced by opioids, as reported previously in mammalian peripheral nerves $[39,40,68]$. A sequence of the opioid-induced CAP peak amplitude reduction was ethylmorphine $>$ codeine $>$ morphine. Thus, CAP amplitude reduction increased in extent with an increase in the number of $-\mathrm{CH}_{2}$ (see Figure 7A in [20] for a comparison of the chemical structures of the three opioids). This result is consistent with the above-mentioned observation that tramadol having $-\mathrm{OCH}_{3}$ in the benzene ring inhibits CAPs more effectively than M1 which is different from tramadol only in terms of the presence of -OH in the ring. Interestingly, this result was obtained in spite of the fact that the chemical structures of morphine, codeine and ethylmorphine are quite distinct from those of tramadol and M1 (see [69] for review). Since the increase in $-\mathrm{CH}_{2}$ number is thought to enhance lipophilicity of opioids, lipophilic opioid-channel interaction is suggested to play a pivotal role in nerve AP conduction block, as shown for local anesthetics [70,71]. This idea is supported by the observation that the potency in CAP inhibition in the rat sciatic nerve was in the order of isopropylcocaine (where the methyl ester group of cocaine is replaced with an isopropyl ester group) $>$ cocaethylene (where its methyl ester group is replaced with an ethyl ester group) $>$ cocaine [72]). It is interesting to note that the sequence of the affinity of opioids for $\mu$-opioid receptors is morphine $>$ codeine $>$ ethylmorphine [73], the order of which is reversed to one for CAP inhibition. If the opioid-induced inhibition of CAPs is mediated by $\mu$-opioid receptors, CAP inhibition sequence will be expected to be morphine $>$ codeine $>$ ethylmorphine. However, this sequence is not seen, a result being consistent with the idea that the opioids-induced frog sciatic nerve CAP inhibition is not mediated by opioid receptors.

The same sequence as that in the frog sciatic nerve has been reported in the rat phrenic nerve [68], although there is a quantitative difference between the two studies. When compared at $5 \mathrm{mM}$, codeine-induced reduction (about 30\%) in frog sciatic nerve CAP peak amplitude was much smaller than that (about $70 \%$ ) in the rat phrenic nerve, while so a large distinction was not seen in morphine action (about 10\%). Frog sciatic nerve CAPs were less sensitive to morphine than those in rabbit and guinea-pig vagus nerves in such that vagus nerve CAP peak amplitudes were reduced by $20-32 \%$ at $0.5 \mathrm{mM}$ [41]. APs recorded intracellularly from rat DRG neurons having $A \alpha / \beta$ myelinated primary-afferent fibers also exhibited the sequence of ethylmorphine $>$ codeine $\geq$ morphine $\left(\mathrm{IC}_{50}=0.70\right.$, 2.5 and $2.9 \mathrm{mM}$, respectively) in AP peak amplitude reduction; this inhibition was resistant to naloxone (0.01 mM) [74].

Although many drugs including narcotics, antiepileptics, local anesthetics, alcohols and barbiturates block AP conduction in peripheral nerve fibers, suggesting a nonspecific interaction of the drugs with membrane bilayers [75], the chemical structure-specific CAP inhibition produced by opioids indicates that opioids act on proteins such as voltage-gated $\mathrm{Na}^{+}$and $\mathrm{K}^{+}$channels (see [76] for review). Morphine is reported to suppress peak $\mathrm{Na}^{+}$currents and steady-state $\mathrm{K}^{+}$currents in single 
myelinated nerve fibers isolated from the frog sciatic nerve, leading to the prolongation of APs [77]. Intracellularly-applied morphine reduced voltage-gated $\mathrm{Na}^{+}$and $\mathrm{K}^{+}$channel current amplitudes in squid giant axons [78]. Bath-applied morphine reduced TTX-sensitive $\mathrm{Na}^{+}$channel current amplitude in DRG neuroblastoma hybridoma cell line ND7/23 cells with an $\mathrm{IC}_{50}$ value of $0.378 \mathrm{mM}$ [64], although Nav1.2 channels expressed in HEK293 cells were unaffected by morphine at $1 \mathrm{mM}$ [65]. In support of such an idea about ion channel inhibition, it has been reported that an opioid meperidine, which is used for AP conduction blockade and thus analgesia, inhibits $\mathrm{Na}^{+}$-channels in a manner similar to that of lidocaine [79]. Table 1 summarizes $\mathrm{IC}_{50}$ values for frog sciatic nerve fast-conducting CAP inhibitions produced by opioids together with those for rat sciatic nerve CAPs and voltage-gated $\mathrm{Na}^{+}$channels.

Table 1. Comparison of $\mathrm{IC}_{50}$ values in inhibiting frog or rat sciatic nerve fast-conducting CAPs and TTX-sensitive $\mathrm{Na}^{+}$channels among opioids.

\begin{tabular}{|c|c|c|c|c|}
\hline Opioids & $\begin{array}{l}\text { Frog CAP } \\
\mathrm{IC}_{50}(\mathrm{mM})\end{array}$ & $\begin{array}{c}\text { Rat CAP } \\
\mathrm{IC}_{50}(\mathrm{mM})\end{array}$ & $\begin{array}{c}\text { TTX-Sensitive } \\
\mathrm{Na}^{+} \text {Channel Current } \\
\mathrm{IC}_{50}(\mathrm{mM})\end{array}$ & References \\
\hline Tramadol & 2.3 & $\begin{array}{l}37 \% \text { reduction } \\
(4 \mathrm{mM})\end{array}$ & $\begin{array}{l}0.194 \\
0.103\end{array}$ & $\begin{array}{c}{[19,59,64]} \\
{[65]}\end{array}$ \\
\hline $\begin{array}{l}\text { Mono-O-desmethyl } \\
\text {-tramadol }\end{array}$ & $\begin{array}{l}9 \% \text { reduction } \\
(5 \mathrm{mM})\end{array}$ & & & [19] \\
\hline Morphine & $\begin{array}{l}15 \% \text { reduction } \\
(5 \mathrm{mM})\end{array}$ & & 0.378 & {$[20,64]$} \\
\hline Codeine & $\begin{array}{l}30 \% \text { reduction } \\
\quad(5 \mathrm{mM})\end{array}$ & & & [20] \\
\hline
\end{tabular}

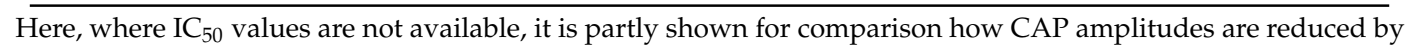
drugs, where $\%$ value indicates the extent of the reduction at the concentration shown in parentheses.

In clinical practice, although administration of opioids into the nerve sheath results in pain relief (for instance, see [80]), many of pain treatments by use of opioids are due to systemic administration of centrally-penetrating opioids, leading to their actions in the PNS and CNS, both of which contribute to analgesia (see [81] for review). It is possible that centrally-administrated opioids act on not only the CNS but also the PNS, because opioids are reported to be transported to the periphery from brain by P-glycoprotein [82]. In support of an important role of opioids in the PNS, subcutaneous administration of $\mathrm{N}$-methyl-morphine, which did not pass through the blood brain barrier, resulted in antinociception in an acetic acid-writhing model in mice [35]. It has been reported that a subcutaneously-administrated opioid loperamide, which cannot penetrate into the brain, exhibited an antinociceptive effect in the formalin test in rats [34]. Such an action of opioids in the PNS appeared to be mediated by opioid receptors in peripheral terminals of primary-afferent fibers ([33-36,83]; see [37] for review). In addition, the inhibitory effect of opioids on nerve AP conduction also might contribute to local analgesia following the peripheral perineural administration of opioids (for instance, see [84]) that are expected to lead to a direct action of opioids at high doses on peripheral nerves. Since codeine is metabolized to morphine via O-demethylation in humans and animals ([85,86]; see [81] for review), peripherally-administrated codeine might have a similar effect to that of morphine.

\subsection{NSAIDs}

Antinociception produced by NSAIDs is mediated by various mechanisms such as (1) inhibition of the synthesis of prostaglandins from arachidonic acid by inhibiting the cyclooxygenase enzyme $([87,88]$; see [89-91] for reviews), (2) inhibition of acid-sensitive ion channels [92] and transient receptor potential (TRP) channels [93,94], (3) activation of several $\mathrm{K}^{+}$channels ([95-99]; see [100,101] for reviews), (4) substance P depletion [102], (5) an interaction with the adrenergic system [103] and (6) an involvement of opioids [104,105] and endocannabinoids (see [106] for review). The idea about an 
involvement of mechanisms other than cyclooxygenase inhibition in antinociception is supported by the observation that there is a dissociation between anti-inflammation and antinociception produced by NSAIDs [107].

An acetic acid-based NSAID diclofenac reduced frog sciatic nerve CAP peak amplitudes in a partially reversible manner. Diclofenac activity was concentration-dependent in a range of $0.01-1 \mathrm{mM}$ with an $\mathrm{IC}_{50}$ value of $0.94 \mathrm{mM}$. Another acetic acid-based NSAID aceclofenac (a carboxymethyl ester of diclofenac) also exhibited a similar CAP inhibitory action. CAP peak amplitudes were concentration-dependently reduced by aceclofenac in a range of $0.01-1 \mathrm{mM}$ with an $\mathrm{IC}_{50}$ of $0.47 \mathrm{mM}$, a value smaller than that of diclofenac. Other acetic acid-based NSAIDs had an efficacy smaller than those of diclofenac and aceclofenac. Indomethacin at $1 \mathrm{mM}$ reduced CAP peak amplitudes by $38 \%$ and acemetacin (where the $-\mathrm{OH}$ group of indomethacin is substituted by $-\mathrm{OCH}_{2} \mathrm{COOH}$ ) at $0.5 \mathrm{mM}$ did so by $38 \%$. Etodolac at $1 \mathrm{mM}$ reduced CAP peak amplitudes by only $15 \%$, and sulindac and felbinac at $1 \mathrm{mM}$ had no effects on CAP peak amplitudes [21].

A similar frog sciatic nerve CAP inhibition was produced by fenamic acid-based NSAIDs (tolfenamic acid, meclofenamic acid, mefenamic acid and flufenamic acid) whose chemical structures are similar to those of diclofenac and aceclofenac. Tolfenamic acid concentration-dependently reduced CAP peak amplitudes in a range of $0.01-0.2 \mathrm{mM}$ with an $\mathrm{IC}_{50}$ value of $0.29 \mathrm{mM}$. The activity of meclofenamic acid (where the chloro group bound to the benzene ring of tolfenamic acid is changed in number and position) was concentration-dependent in a range of $0.01-0.5 \mathrm{mM}$ with an $\mathrm{IC}_{50}$ value of $0.19 \mathrm{mM}$. Moreover, mefenamic acid (where the chloro group bound to the benzene ring of tolfenamic acid is replaced by methyl group) concentration-dependently reduced CAP peak amplitudes in a range of $0.01-0.2 \mathrm{mM}$ with the extent of $16 \%$ at $0.2 \mathrm{mM}$. CAP peak amplitudes were concentration-dependently reduced by flufenamic acid (where one out of two methyl groups bound to the benzene ring of mefenamic acid is lacking and another one is replaced by $-\mathrm{CF}_{3}$ ) with an $\mathrm{IC}_{50}$ of $0.22 \mathrm{mM}$, a value comparable to those of tolfenamic acid and meclofenamic acid [21].

2,6-Dichlorodiphenylamine and N-phenylanthranilic acid (which are similar in chemical structure to diclofenac and tolfenamic acid while being not NSAIDs) reduced frog sciatic nerve CAP peak amplitudes; the former compound lacks the $-\mathrm{CH}_{2} \mathrm{COOH}$ group of diclofenac and the latter one lacks chloro and methyl groups bound to the benzene ring of tolfenamic acid. 2,6-Dichloro- diphenylamine activity was concentration-dependent in a range of $0.001-0.1 \mathrm{mM}$ with the extent of $45 \%$ at $0.1 \mathrm{mM}$; $\mathrm{N}$-phenylanthranilic acid activity was concentration-dependent in a range of $0.01-2 \mathrm{mM}$ with the extent of $23 \%$ at $1 \mathrm{mM}$ [21].

With respect to other types of NSAIDs, salicylic acid-based (aspirin; $1 \mathrm{mM}$ ), propionic acid-based (ketoprofen, naproxen, ibuprofen, loxoprofen and flurbiprofen; each $1 \mathrm{mM}$ ) and enolic acid-based [meloxicam $(0.5 \mathrm{mM})$ and piroxicam $(1 \mathrm{mM})$ ] NSAIDs had no effects on frog sciatic nerve CAP amplitudes [21].

CAP amplitude reductions produced by the NSAIDs would be mediated by an inhibition of TTX-sensitive voltage-gated $\mathrm{Na}^{+}$channels that are involved in frog CAP production. In support of this idea, diclofenac decreased the peak amplitudes of TTX-sensitive $\mathrm{Na}^{+}$-channel currents in rat DRG [108] and mouse trigeminal ganglion neurons [109]. A similar diclofenac-induced $\mathrm{Na}^{+}$-channel inhibition has been reported in rat myoblasts [110] and ventricular cardiomyocytes [111]. Flufenamic acid as well as diclofenac decreased $\mathrm{Na}^{+}$-channel current amplitudes in rat hippocampal CA1 neurons [112-114]. Although $\mathrm{IC}_{50}$ value $(0.22 \mathrm{mM})$ for flufenamic acid in frog sciatic nerve CAP inhibition was similar to that of $\mathrm{Na}^{+}$channel inhibition $(0.189 \mathrm{mM})$ in rat hippocampal CA1 neurons [114], $\mathrm{IC}_{50}$ value (0.94 $\mathrm{mM}$ ) for diclofenac in CAP inhibition was much larger than those $(0.00851$ and $0.014 \mathrm{mM}$ in rat myoblasts and DRG neurons, respectively) of $\mathrm{Na}^{+}$channel inhibition $[108,110]$. Regarding rank order among NSAIDs, the order for CAP inhibition at $0.5 \mathrm{mM}$ was flufenamic acid $>$ diclofenac $>$ indomethacin $>>$ aspirin $=$ naproxen $=$ ibuprofen [21]; this was in part similar to those for $\mathrm{Na}^{+}$channel inhibition in rat cardiomyocytes (diclofenac $>$ naproxen $\geq$ ibuprofen; [111]) and also in rat DRG neurons (diclofenac $>$ flufenamic acid $>$ indomethacin $>$ aspirin; [108]). With respect to TTX-resistant 
$\mathrm{Na}^{+}$channels, diclofenac at $0.3 \mathrm{mM}$ reduced peak current amplitudes by about $20 \%$ in rat trigeminal ganglion neurons [115]; Nav1.8 channel currents were inhibited by flufenamic acid and tolfenamic acid (current amplitude reduction: ca. 30 and 30\%, respectively, at $0.1 \mathrm{mM}$; [116]). TTX-sensitive Nav1.7 channel currents were more sensitive to flufenamic acid and tolfenamic acid (reduction: ca. 60 and $70 \%$, respectively, at $0.1 \mathrm{mM}$ ) than Nav1.8 ones [116]. Alternatively, chemical irritation-induced activity increase of cat corneal sensory nerve fibers was suppressed in extent by NSAIDs; this suppression was different in magnitude among distinct types of NSAIDs $[109,117] . \mathrm{Na}^{+}$-channel inhibition produced by NSAIDs appeared to be different in extent among preparations. Concentrations required for NSAIDs to have a significant inhibitory effect on frog sciatic nerve CAPs were in general higher than those needed to inhibit $\mathrm{Na}^{+}$channels; this may be attributed to various reasons including the fact that not only $\mathrm{Na}^{+}$channels but also $\mathrm{K}^{+}$channels are involved in determining CAP amplitudes. To my knowledge, the effects of aceclofenac, indomethacin, etodolac, acemetacin, meclofenamic acid and mefenamic acid on voltage-gated $\mathrm{Na}^{+}$channels have not been reported. Table 2 summarizes $\mathrm{IC}_{50}$ values for frog sciatic nerve fast-conducting CAP inhibitions produced by NSAIDs together with those for voltage-gated $\mathrm{Na}^{+}$channels.

Table 2. Comparison of $\mathrm{IC}_{50}$ values in inhibiting frog sciatic nerve fast-conducting CAPs, TTX-sensitive or -resistant $\mathrm{Na}^{+}$channels among NSAIDs.

\begin{tabular}{|c|c|c|c|c|c|}
\hline & AIDs & $\begin{array}{l}\text { Frog CAP } \\
\mathrm{IC}_{50}(\mathrm{mM})\end{array}$ & $\begin{array}{c}\text { TTX-Sensitive } \\
\mathrm{Na}^{+} \text {Channel } \\
\text { Current } \mathrm{IC}_{50}(\mathrm{mM})\end{array}$ & $\begin{array}{c}\text { TTX-Resistant } \\
\mathrm{Na}^{+} \text {Channel } \\
\text { Current } \mathrm{IC}_{50}(\mathrm{mM})\end{array}$ & References \\
\hline \multirow{7}{*}{$\begin{array}{c}\text { Acetic } \\
\text { Acid-Based }\end{array}$} & Diclofenac & 0.94 & $0.00851,0.014$ & $\begin{array}{c}\text { ca. } 20 \% \text { reduction } \\
(0.3 \mathrm{mM})\end{array}$ & {$[21,108,110,115]$} \\
\hline & Aceclofenac & 0.47 & & & [21] \\
\hline & Indomethacin & $38 \%$ reduction $(1 \mathrm{mM})$ & & & [21] \\
\hline & Acemetacin & $38 \%$ reduction $(0.5 \mathrm{mM})$ & & & [21] \\
\hline & Etodolac & $15 \%$ reduction $(1 \mathrm{mM})$ & & & [21] \\
\hline & Sulindac & $\begin{array}{c}\text { n.d. } \\
\text { (no effect, } 1 \mathrm{mM} \text { ) }\end{array}$ & & & [21] \\
\hline & Felbinac & $\begin{array}{c}\text { n.d. } \\
\text { (no effect, } 1 \mathrm{mM} \text { ) }\end{array}$ & & & [21] \\
\hline \multirow{5}{*}{$\begin{array}{c}\text { Fenamic } \\
\text { Acid-Based }\end{array}$} & Tolfenamic acid & 0.29 & $\begin{array}{c}\text { ca. } 70 \% \text { reduction } \\
(0.1 \mathrm{mM})\end{array}$ & $\begin{array}{c}\text { ca. } 30 \% \text { reduction } \\
(0.1 \mathrm{mM})\end{array}$ & {$[21,116]$} \\
\hline & Meclofenamic acid & 0.19 & & & [21] \\
\hline & Mefenamic acid & $16 \%$ reduction $(0.2 \mathrm{mM})$ & & & [21] \\
\hline & Flufenamic acid & 0.22 & $\begin{array}{c}\text { ca. } 60 \% \text { reduction } \\
(0.1 \mathrm{mM})\end{array}$ & $\begin{array}{c}\text { ca. } 30 \% \text { reduction } \\
(0.1 \mathrm{mM})\end{array}$ & {$[21,116]$} \\
\hline & & & 0.189 & & [114] \\
\hline $\begin{array}{c}\text { Salicylic } \\
\text { Acid-Based }\end{array}$ & Aspirin & $\begin{array}{c}\text { n.d. } \\
\text { (no effect, } 1 \mathrm{mM} \text { ) }\end{array}$ & & & [21] \\
\hline \multirow{5}{*}{$\begin{array}{l}\text { Propionic } \\
\text { Acid-Based }\end{array}$} & Ketoprofen & $\begin{array}{c}\text { n.d. } \\
\text { (no effect, } 1 \mathrm{mM} \text { ) }\end{array}$ & & & [21] \\
\hline & Naproxen & $\begin{array}{c}\text { n.d. } \\
\text { (no effect, } 1 \mathrm{mM} \text { ) }\end{array}$ & & & [21] \\
\hline & Ibuprofen & $\begin{array}{c}\text { n.d. } \\
\text { (no effect, } 1 \mathrm{mM} \text { ) }\end{array}$ & & & [21] \\
\hline & Loxoprofen & $\begin{array}{c}\text { n.d. } \\
\text { (no effect, } 1 \mathrm{mM} \text { ) }\end{array}$ & & & [21] \\
\hline & Flurbiprofen & $\begin{array}{c}\text { n.d. } \\
\text { (no effect, } 1 \mathrm{mM} \text { ) }\end{array}$ & & & [21] \\
\hline \multirow{2}{*}{$\begin{array}{c}\text { Enolic } \\
\text { Acid-Based }\end{array}$} & Meloxicam & $\begin{array}{c}\text { n.d. } \\
\text { (no effect, } 0.5 \mathrm{mM} \text { ) }\end{array}$ & & & [21] \\
\hline & Piroxicam & $\begin{array}{c}\text { n.d. } \\
\text { (no effect, } 1 \mathrm{mM} \text { ) }\end{array}$ & & & [21] \\
\hline
\end{tabular}

Here, when $\mathrm{IC}_{50}$ values are not available, it is partly shown for comparison how the CAPs and channels are affected by drugs, where \% value indicates the extent of the reduction at the concentration shown in parentheses; n.d.: not determined. 
NSAIDs (diclofenac, aceclofenac, tolfenamic acid, meclofenamic acid and flufenamic acid), which are more effective in frog sciatic nerve CAP inhibition compared to the other NSAIDs [21], have two benzene rings that bind a hydrophilic substituent group, both of which rings are linked by - $\mathrm{NH}$ - (see Figures $1 \mathrm{Aa}, 1 \mathrm{Ba}, 3 \mathrm{Aa}, 3 \mathrm{Ba}, 3 \mathrm{Da}$ in [21] for the chemical structures of the five NSAIDs), as seen in local anesthetics (see Section 3.4). Mefenamic acid (where one of the two benzene rings has a hydrophobic substituent group; see Figure 3Ca in [21]) appeared to be less effective, albeit not examined at a higher concentration due to a less solubility of this drug (see above). CAPs were effectively inhibited by 2,6-dichlorodiphenylamine and N-phenylanthranilic acid that are not NSAIDs while being similar in chemical structure to NSAIDs having two benzene rings (see Figures 4Aa and 4Ba in [21]). CAPs were also depressed by bisphenol A that have two benzene rings that bind a hydrophilic group such as $-\mathrm{OH}[26]$.

Much evidence demonstrates that the other actions of NSAIDs depend on their chemical structures. For instance, an involvement of NO-cGMP-K ${ }^{+}$channels in antinociception mediated by NSAIDs was dependent on their chemical structures $[98,118]$. Nonselective cation channels in the rat exocrine pancreas were suppressed by flufenamic acid and mefenamic acid but not indomethacin, aspirin and ibuprofen [119]. There was a distinction in depressing TRP melastatin-3 channels between diclofenac and aceclofenac [94]. Although NSAIDs not only suppress but also activate TRP ankyrin-1 channels, this activation also differed in magnitude among NSAIDs [120]. Moreover, there was a distinction among NSAIDs in the activities of mitochondrial oxidative phosphorylation or electron transport system that may be involved in their adverse side effects [121].

Although the concentrations of NSAIDs tested in the frog sciatic nerve are generally much higher than those for voltage-gated $\mathrm{Na}^{+}$-channel inhibition, such high concentrations are likely when NSAIDs are used at high concentrations in the direct vicinity of nerve fibers. At least a part of analgesia caused by NSAIDs used as a dermatological drug for antinociception may be due to a nerve conduction inhibition through their inhibitory action on voltage-gated $\mathrm{Na}^{+}$channels [122].

\section{Actions of Analgesic Adjuvants on Nerve Conduction}

\subsection{Adrenoceptor Agonists}

Intrathecally or epidurally administrated $\alpha_{2}$ agonists such as clonidine and DEX (see [123] for review) produce analgesia in animals [124-126] and humans [127]. This is possibly due to inhibited glutamatergic excitatory transmission in spinal superficial dorsal horn neurons [128]. $\alpha_{2}$ Agonists combined with local anesthetics in spinal anesthesia extend the duration of peripheral nerve block in animals [129,130] and humans ([131-136]; see [137] for a review). This is possibly mediated by a contraction of local vessels by the agonists, resulting in a decrease in the clearance of the anesthetics from the subarachnoid space $[138,139]$. Moreover, $\alpha_{2}$ agonists suppress nerve AP conduction and therefore exhibit a local anesthetic effect, contributing to enhanced local anesthetic effect [140]. For example, clonidine not only inhibits excitatory transmission in rat spinal lamina II neurons $[141,142]$ but also blocks AP conduction in peripheral nerves $[140,143,144]$. The latter action requires a much higher concentration of clonidine than the former one. DEX as well as clonidine is reported to depress excitatory transmission in rat lamina II neurons [145]. Intracutaneous administration of DEX or clonidine together with lidocaine into the back of guinea-pigs increases in extent the local anesthetic effect of lidocaine [146]. Local wound infiltration with DEX added to bupivacaine more effectively alleviated postoperative pain compared to bupivacaine alone in humans [147]. It is possible that DEX as well as clonidine has a suppressive action on AP conduction, because DEX reportedly depresses voltage-gated $\mathrm{Na}^{+}$-channel currents [148].

DEX reduced the peak amplitude of frog sciatic nerve CAPs in a concentration-dependent manner in a range of $0.01-1 \mathrm{mM}$ with an $\mathrm{IC}_{50}$ value of $0.40 \mathrm{mM}$ [22]. Although DEX exhibited a high affinity for $\alpha_{2}$ adrenoceptors [123], DEX activity was not inhibited by $\alpha_{2}$-adrenoceptor antagonists, yohimbine and atipamezole ([128,149-151]; see [152,153] for reviews), indicating no involvement of $\alpha_{2}$ 
adrenoceptors [22]. CAP inhibition was also seen by other $\alpha_{2}$-adrenoceptor agonists, oxymetazoline (more selective to $\alpha_{2 \mathrm{~A}}$ than $\alpha_{2 \mathrm{~B}}$ and $\alpha_{2 \mathrm{C}}$; see $[152,154]$ for reviews) and clonidine in a manner resistant to yohimbine. Oxymetazoline reduced CAP peak amplitude with an $\mathrm{IC}_{50}$ value of $1.5 \mathrm{mM}$; CAP amplitude was reduced by about $20 \%$ by clonidine at $2 \mathrm{mM}$ [22]. This clonidine activity was different in extent from that $(80 \%$ CAP amplitude reduction at $0.3 \mathrm{mM})$ reported previously for frog sciatic nerve CAPs [144], albeit a reason for this discrepancy is unknown. On the other hand, various adrenoceptor agonists, adrenaline, NA, $\alpha_{1}$-adrenoceptor agonist phenylephrine and $\beta$-adrenoceptor agonist isoproterenol at $1 \mathrm{mM}$ had no effect on frog sciatic nerve CAPs [22]. A similar CAP inhibition produced by clonidine has been reported in the rat sciatic nerve. It has been demonstrated that CAPs originating from primary-afferent $\mathrm{A} \alpha$ and $\mathrm{C}$ fibers in the rat sciatic nerve are inhibited by clonidine with $\mathrm{IC}_{50}$ values of 2.0 and $0.45 \mathrm{mM}$, respectively [143].

The CAP inhibitory action of $\alpha_{2}$-adrenoceptor agonists would be due to an inhibition of voltage-gated $\mathrm{Na}^{+}$and $\mathrm{K}^{+}$channels involved in AP production. It has been reported that DEX inhibits voltage-gated $\mathrm{Na}^{+}$channels in rat DRG neurons in a manner insensitive to yohimbine, although this type of $\mathrm{Na}^{+}$channels is resistant to TTX [148]. IC 50 value $(0.058 \mathrm{mM})$ for this DEX activity in rat DRG neurons was about 10 -fold smaller than that $(0.40 \mathrm{mM})$ of frog CAP inhibition. The rat TTX-resistant $\mathrm{Na}^{+}$channel was also inhibited by clonidine with an $\mathrm{IC}_{50}$ value of $0.26 \mathrm{mM}$ [148]. TTX-sensitive $\mathrm{Na}^{+}$channels in DRG neuroblastoma hybridoma cell line ND7/23 cells were inhibited by clonidine $\left(\mathrm{IC}_{50}=0.824 \mathrm{mM}\right.$; [155]). It has been reported in NG108-15 neuronal cells that delayed-rectifier $\mathrm{K}^{+}$-channels are inhibited by DEX with an $\mathrm{IC}_{50}$ value of $0.0046 \mathrm{mM}$ and that TTX-sensitive $\mathrm{Na}^{+}$-channel current amplitudes are reduced by about $20 \%$ by DEX $(0.01 \mathrm{mM})$ in a manner insensitive to yohimbine [156]. These distinctions in potency of drugs may be due to a difference in either animal species or $\mathrm{Na}^{+}$-channel types. Table 3 summarizes $\mathrm{IC}_{50}$ values for frog sciatic nerve fast-conducting CAP inhibitions produced by adrenoceptor agonists together with those for rat sciatic nerve CAPs and voltage-gated $\mathrm{Na}^{+}$channels.

Table 3. Comparison of $\mathrm{IC}_{50}$ values in inhibiting frog or rat sciatic nerve fast-conducting CAPs and TTX-sensitive or -resistant $\mathrm{Na}^{+}$channels among adrenoceptor agonists.

\begin{tabular}{|c|c|c|c|c|c|c|}
\hline \multicolumn{2}{|c|}{$\begin{array}{l}\text { Adrenoceptor } \\
\text { Agonists }\end{array}$} & $\begin{array}{c}\text { Frog } \\
\text { CAP } \\
\mathrm{IC}_{50}(\mathrm{mM})\end{array}$ & $\begin{array}{c}\text { Rat } \\
\text { CAP } \\
\mathrm{IC}_{50}(\mathrm{mM})\end{array}$ & $\begin{array}{l}\text { TTX-Sensit. } \\
\mathrm{Na}^{+} \text {Channel } \\
\text { Current } \\
\mathrm{IC}_{50}(\mathrm{mM})\end{array}$ & $\begin{array}{c}\text { TTX-Resist. } \\
\mathrm{Na}^{+} \text {Channel } \\
\text { Current } \\
\mathrm{IC}_{50}(\mathrm{mM})\end{array}$ & References \\
\hline & Adrenaline & $\begin{array}{c}\text { n.d. } \\
\text { (no effect, } 1 \mathrm{mM} \text { ) }\end{array}$ & & & & [22] \\
\hline & Noradrenaline & $\begin{array}{c}\text { n.d. } \\
\text { (no effect, } 1 \mathrm{mM} \text { ) }\end{array}$ & & & & [22] \\
\hline \multirow{3}{*}{$\alpha_{2}$ Agonist } & Dexmedetomidine & 0.40 & & $\begin{array}{l}\text { ca. } 20 \% \text { reduct. } \\
\quad(0.01 \mathrm{mM})\end{array}$ & 0.058 & {$[22,148,156]$} \\
\hline & Oxymetazoline & 1.5 & & & & [22] \\
\hline & Clonidine & $\begin{array}{l}\text { ca. } 20 \% \text { reduct. } \\
(2 \mathrm{mM})\end{array}$ & 2.0 & 0.824 & 0.26 & {$[22,143,148,155]$} \\
\hline$\alpha_{1}$ Agonist & Phenylephrine & $\begin{array}{c}\text { n.d. } \\
\text { (no effect, } 1 \mathrm{mM} \text { ) }\end{array}$ & & & & [22] \\
\hline$\beta$ Agonist & Isoproterenol & $\begin{array}{c}\text { n.d. } \\
\text { (no effect, } 1 \mathrm{mM} \text { ) }\end{array}$ & & & & [22] \\
\hline
\end{tabular}

Here, when $\mathrm{IC}_{50}$ values are not available, it is partly shown for comparison how the CAPs and channels are affected by drugs. sensit.: sensitive; resist.: resistant; reduct.: reduction (where \% value indicates the extent of the reduction at the concentration shown in parentheses); n.d.: not determined.

In clinical practice, DEX produces analgesia/sedation and decrease in heart rate, cardiac output and memory, each of whose actions depends on the plasma concentration of DEX in a distinct manner [157]. In patients, sedation is rapidly produced by 0.2 to $0.7 \mathrm{mg} \cdot \mathrm{kg}^{-1} \cdot \mathrm{h}^{-1}$ i.v. [123]; in intramuscular administration in cats, $40 \mathrm{mg} \cdot \mathrm{kg}^{-1}$ is a usual dose for analgesia/sedation [158]. DEX concentrations, which are enough to suppress nerve AP conduction, are $>1000$-fold higher than the use of DEX as $\alpha_{2}$ agonist, because the clinical use of DEX is $<0.05 \mu \mathrm{M}$ for plasma levels (see [157]). Therefore, the potential 
of DEX for nerve AP conduction block is independent of the use of DEX for analgesia/sedation. $\alpha_{2}$-Adrenoceptor agonists such as DEX, combined with a local anesthetic, have been used to extend peripheral nerve AP conduction block duration [130,132-135,159]. This effect is possibly due to a local vasoconstriction resulting in a delay of the absorption of the local anesthetic and/or a direct nerve AP conduction inhibition by $\alpha_{2}$ agonists [136]. The latter mechanism would be the above-mentioned nerve CAP inhibition produced by $\alpha_{2}$ agonists. This action makes sense when considering their topical application on nerves, but is not related to their use for analgesia/anesthesia by systemic administration. A chemical structure related to their $\alpha_{2}$ agonists (see [22]) may play a pivotal role in producing nerve AP conduction block.

\subsection{Antiepileptics}

Antiepileptics have various actions including $\mathrm{GABA}_{\mathrm{A}}$-receptor activation, and voltage-gated $\mathrm{Na}^{+}-\mathrm{Ca}^{2+}$-channel and glutamate-receptor inhibition (see [11,160] for reviews). As indicated by the inhibitory action on $\mathrm{Na}^{+}$channel, nerve AP conduction inhibition is important for antiepileptics to alleviate neuropathic pain.

Frog sciatic nerve CAPs were inhibited by a phenyltriazine derivative (3,5-diamino6-(2,3-dichlorophenyl)-1,2,4-triazine; lamotrigine) that suppressed voltage-gated $\mathrm{Na}^{+}$channels [161], and relieved central post-stroke pain and painful diabetic polyneuropathy [5]. This lamotrigine activity was partially reversible and concentration-dependent in a range of $0.02-0.5 \mathrm{mM}$ with an $\mathrm{IC}_{50}$ value of $0.44 \mathrm{mM}$ [23]. A similar CAP inhibition was seen by carbamazepine (5H-dibenz[b,f]azepine-5-carboxamide, an iminostilbene derivative [23]), which is different in chemical structure from lamotrigine while depressing voltage-gated $\mathrm{Na}^{+}$channels [162]. Carbamazepine is known to be effective to relieve trigeminal neuralgia (see $[163,164]$ for reviews). As different from lamotrigine, carbamazepine reduced frog sciatic nerve CAP amplitudes in a complete and reversible manner. This activity was concentration-dependent in a range of $0.05-1 \mathrm{mM}$ with an $\mathrm{IC}_{50}$ value of $0.50 \mathrm{mM}$ [23]. 10,11-Dihydro-10-oxo-5H-dibenz[b,f]-azepine- 5-carboxamide (oxcarbazepine, [165]), where there is a keto substitution at the 10,11 position of the dibenzazepine nucleus of carbamazepine, inhibited frog sciatic nerve CAPs with an efficacy smaller than that of carbamazepine [23]. Oxcarbazepine is reported to be effective in relieving painful diabetic neuropathy [5] and trigeminal neuralgia [163]. Oxcarbazepine activity was partially reversible and concentration-dependent in a range of $0.02-0.7 \mathrm{mM}$. When compared at $0.7 \mathrm{mM}, \mathrm{CAP}$ amplitude reduction by oxcarbazepine ( $40 \%$ ) was somewhat smaller than that of carbamazepine (57\%). Each of lamotrigine, carbamazepine and oxcarbazepine at $0.5 \mathrm{mM}$ increased a threshold to evoke frog sciatic nerve CAPs [23]. This observation may be consistent with the fact that the antiepileptics reduce $\mathrm{Na}^{+}$-channel current amplitudes with a shift of their steady-state inactivation to a more negative membrane potential [166-168]. Another antiepileptic phenytoin (hydantoin derivative, 5,5-diphenylhydantoin; which inhibits voltage-gated $\mathrm{Na}^{+}$channels [169] and alleviates paroxysm in trigeminal neuralgia [164]) reduced by a small extent frog sciatic nerve CAP peak amplitudes in a concentration-dependent manner in a range of $0.01-0.1 \mathrm{mM}$; this extent was only $15 \%$ at $0.1 \mathrm{mM}$ [23].

When CAP and $\mathrm{Na}^{+}$channel inhibition produced by antiepileptics were compared, the lamotrigine's $\mathrm{IC}_{50}$ value $(0.44 \mathrm{mM})$ in the frog sciatic nerve was close to that $(0.641 \mathrm{mM}$ at $-90 \mathrm{mV})$ in inhibiting TTX-sensitive human brain type IIA Na${ }^{+}$channels expressed in Chinese hamster ovary cells [161]. Consistent with the fact that lamotrigine and carbamazepine had comparable $\mathrm{IC}_{50}$ values in the frog sciatic nerve, they reduced $\mathrm{Na}^{+}$-channel current amplitudes in N4TG1 mouse neuroblastoma cells with $\mathrm{IC}_{50}$ values similar to each other [168]. Oxcarbazepine at $0.5 \mathrm{mM}$ reduced frog sciatic nerve CAP peak amplitudes by $20 \%$ [23]; this activity was much smaller than that for TTX-sensitive $\mathrm{Na}^{+}$-channel current reduction in differentiated NG108-15 neuronal cells $\left(\mathrm{IC}_{50}=3.1 \mu \mathrm{M}\right.$; [166]). The smaller CAP inhibition by oxcarbazepine than carbamazepine in the frog sciatic nerve may be consistent with the fact that oxcarbazepine was less effective than carbamazepine in suppressing seizures produced by maximal electroshock in rats [165]. The activity of phenytoin (CAP amplitude 
reduction of $15 \%$ at $0.1 \mathrm{mM}$ ) in the frog sciatic nerve was less than those for rat cortical and human type IIA $\mathrm{Na}^{+}$channels $(60-90 \%$ amplitude reduction at $-60 \mathrm{mV}$ by phenytoin at $0.1 \mathrm{mM})[161,169]$. As different from frog sciatic nerve CAPs, phenytoin reduced $\mathrm{Na}^{+}$channel current amplitudes in N4TG1 mouse neuroblastoma cells with an $\mathrm{IC}_{50}$ value similar to that of lamotrigine [168]; phenytoin, lamotrigine and carbamazepine were reported to bind to a common site of $\mathrm{Na}^{+}$channels in rat hippocampal CA1 neurons [167]. A sensitivity of voltage-gated $\mathrm{Na}^{+}$channels to phenytoin may be different in extent among distinct types of the channel. Consistent with this idea, phenytoin actions differed among human Nav1.1, Nav1.2, Nav1.3 and Nav1.4 $\alpha$-subunits (all of which are TTX-sensitive) expressed in HEK293 cells [170]; there was a distinction in the properties and accessibilities of $\mathrm{Na}^{+}$ channels between frog and rat myelinated nerves [171].

Antiepileptics having an ability to suppress CAPs are similar in chemical structure to NSAIDs in that lamotrigine, carbamazepine and oxcarbazepine have two unsaturated six-membered rings (see Figures 1a, 2aA and 2bA in [23] for the chemical structures of the three antiepileptics). Carbamazepine and diclofenac appear to have a common or closely related binding site owing to an occlusion of their effects on voltage-gated $\mathrm{Na}^{+}$channels [113].

On the other hand, frog sciatic nerve CAPs were not affected by other antiepileptics, gabapentin (1-(aminomethyl)cyclohexaneacetic acid; which is related to GABA in chemical structure and relieves post-herpetic neuralgia [164]), topiramate (2,3:4,5-bis-O-(1-methylethylidene)- $\beta$-D-fructopyranose sulfamate; which alleviates various neuropathic pains including intercostal neuralgia and trigeminal neuralgia [11]) and sodium valproate (2-propylpentanoic acid sodium salt; which relieves diabetic neuropathic pain [11]), at a high concentration such as $10 \mathrm{mM}$ [23].

The less effectiveness of gabapentin and sodium valproate in the frog sciatic nerve was similar to that for human type IIA $\mathrm{Na}^{+}$channels [161]. Gabapentin at concentrations of $<3 \mathrm{mM}$ hardly affected the human $\mathrm{Na}^{+}$channels [161]. Gabapentin's antinociceptive action would be mainly due to its binding to the $\alpha_{2} \delta$ subunit of voltage-gated $\mathrm{Ca}^{2+}$ channels, leading to an inhibition of $\mathrm{Ca}^{2+}$ entry in nerve terminals which in turn suppresses the release of neurotransmitters from there (see [172] for review). As different from the frog sciatic nerve, topiramate reduced TTX-sensitive $\mathrm{Na}^{+}$-channel current amplitudes with an $\mathrm{IC}_{50}$ value of $0.0489 \mathrm{mM}$ in rat cerebellar granule cells [173]. Such a distinction would be possibly attributed to a difference in topiramate sensitivity among different types or phosphorylation states of $\mathrm{Na}^{+}$channels [174]. Antinociceptive actions of sodium valproate and topiramate have been attributed to other mechanisms such as $\mathrm{GABA}_{\mathrm{A}}$-receptor response increase (see $[175,176]$ for reviews). Glutamate-receptor inhibition also would possibly contribute to the antinociceptions produced by topiramate and lamotrigine, because topiramate suppresses GluK1 (GluR5) kainate receptors (a subtype of glutamate receptors) in rat basolateral amygdala neurons [177] and lamotrigine depresses $\alpha$-amino-3-hydroxy-5-methyl-4-isoxazole propionate (AMPA) receptors (another subtype of glutamate receptors) in rat dentate gyrus granule cells [178]. Table 4 summarizes $\mathrm{IC}_{50}$ values for frog sciatic nerve fast-conducting CAP inhibitions produced by antiepileptics together with those for voltage-gated $\mathrm{Na}^{+}$channels.

Antiepileptics having an ability to suppress frog sciatic nerve CAPs appeared to have antinociceptive actions in a persistent pain model. Intraperitoneal administration of lamotrigine, carbamazepine and oxcarbazepine produced analgesic effects in the second phase of the formalin test whereas phenytoin, topiramate and sodium valproate did not in rats $[179,180]$. The antinociceptive effects of antiepileptics seemed to be related to nerve AP conduction inhibition produced by them. The plasma concentrations of lamotrigine and carbamazepine used to clinically treat epilepsy are, respectively, $<12$ and 20-50 $\mu \mathrm{M}$ [181,182], values smaller than those of $\mathrm{IC}_{50}$ for frog sciatic nerve CAP inhibition. 
Table 4. Comparison of $\mathrm{IC}_{50}$ values in inhibiting frog sciatic nerve fast-conducting CAPs and TTX-sensitive $\mathrm{Na}^{+}$channels among antiepileptics.

\begin{tabular}{|c|c|c|c|}
\hline Antiepileptics & $\begin{array}{l}\text { Frog CAP } \\
\mathrm{IC}_{50}(\mathrm{mM})\end{array}$ & $\begin{array}{c}\text { TTX-Sensitive } \\
\mathrm{Na}^{+} \text {Channel Current } \\
\mathrm{IC}_{50}(\mathrm{mM})\end{array}$ & References \\
\hline Lamotrigine & 0.44 & $\begin{array}{c}0.641 \\
(\text { at }-90 \mathrm{mV})\end{array}$ & {$[23,161]$} \\
\hline Carbamazepine & 0.50 & & [23] \\
\hline Oxcarbazepine & $\begin{array}{l}20 \% \text { reduction } \\
\quad(0.5 \mathrm{mM})\end{array}$ & 0.0031 & {$[23,166]$} \\
\hline Phenytoin & $\begin{array}{l}15 \% \text { reduction } \\
(0.1 \mathrm{mM})\end{array}$ & $\begin{array}{c}60-90 \% \text { reduction } \\
(0.1 \mathrm{mM} \text { at }-60 \mathrm{mV})\end{array}$ & {$[23,161,169]$} \\
\hline Gabapentin & $\begin{array}{c}\text { n.d. } \\
\text { (no effect, } 10 \mathrm{mM} \text { ) }\end{array}$ & $\begin{array}{l}\text { no effect } \\
(<3 \mathrm{mM})\end{array}$ & {$[23,161]$} \\
\hline Topiramate & $\begin{array}{c}\text { n.d. } \\
\text { (no effect, } 10 \mathrm{mM} \text { ) }\end{array}$ & 0.0489 & {$[23,173]$} \\
\hline Sodium valproate & $\begin{array}{c}\text { n.d. } \\
\text { (no effect, } 10 \mathrm{mM} \text { ) }\end{array}$ & & [23] \\
\hline
\end{tabular}

\subsection{Antidepressants}

Cellular mechanisms for antinociception produced by antidepressants are thought to be activation of the 5-HT- and NA-containing descending antinociceptive pathway to spinal dorsal horn through an inhibition of the reuptake of their neurotransmitters [183,184], involvement of $\alpha$ adrenoceptors, $\mathrm{H}_{1}$-histamine, 5-HT, opioid and muscarinic acetylcholine receptors ([9,185-188]; see [189,190] for reviews) and inhibition of voltage-gated $\mathrm{Ca}^{2+}[191,192], \mathrm{N}$-methyl-D-aspartate (NMDA)-receptor

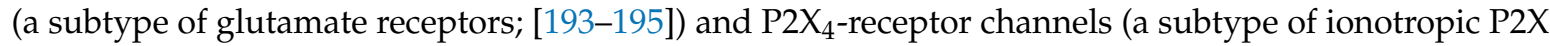
receptors; [196]), all of which are related to synaptic transmission.

Frog sciatic nerve CAPs were inhibited by a 5-HT and NA reuptake inhibitor (SNRI) duloxetine ([197-199]; see [200] for review) in a partially reversible manner. Duloxetine activity was concentration-dependent in a range of $0.001-2 \mathrm{mM}$ with an $\mathrm{IC}_{50}$ value of $0.23 \mathrm{mM}$ [24]. A similar CAP inhibition was produced by a selective 5-HT reuptake inhibitor (SSRI) fluoxetine $([185,186]$; see $[190,201]$ for reviews). Fluoxetine reduced frog sciatic nerve CAP peak amplitudes; this activity was partially reversible, concentration-dependent in a range of $0.05-5 \mathrm{mM}$ and had an $\mathrm{IC}_{50}$ of $1.5 \mathrm{mM}$, a value larger than that of duloxetine [24].

Typical tricyclic antidepressants (amitriptyline and desipramine, which are tertiary and secondary amines, respectively; $[184,187,202,203])$ exhibited a similar inhibitory action on frog sciatic nerve CAPs. CAP peak amplitudes were reduced by amitriptyline in a concentration range of $0.001-1 \mathrm{mM}$ with an $\mathrm{IC}_{50}$ value of $0.26 \mathrm{mM}$, and by desipramine in a concentration range of $0.1-5 \mathrm{mM}$ with an $\mathrm{IC}_{50}$ value of $1.6 \mathrm{mM}$ [24]. Thus, amitriptyline was six-fold more effective than desipramine in inhibiting CAPs. The activity of amitriptyline was consistent with its AP conduction blockade action in the rat sciatic nerve [204].

As with tricyclic antidepressants, a tetracyclic one maprotiline [202] also reduced frog sciatic nerve CAP peak amplitudes in a partially reversible manner. Maprotiline activity was concentration-dependent in a range of $0.2-5 \mathrm{mM}$ with an $\mathrm{IC}_{50}$ value of $0.95 \mathrm{mM}$ [24]. Trazodone, which is known as 5-HT 2 antagonist and reuptake inhibitor (SARI), is a non-SNRI, -SSRI, -tricyclic and -tetracyclic antidepressant ([205-208]; see [209] for review). Frog sciatic nerve CAPs were inhibited by trazodone at concentrations ranging from 0.2 to $2 \mathrm{mM}$, a maximally dissolved one, in a partially 
reversible manner. The extent of CAP peak amplitude reduction by trazodone at $1.0 \mathrm{mM}$ was about $50 \%$ [24].

The CAP amplitude reductions produced by the antidepressants would be mediated by an inhibition of TTX-sensitive voltage-gated $\mathrm{Na}^{+}$channels which are involved in producing frog sciatic nerve CAPs. This idea is supported by the observations that voltage-gated $\mathrm{Na}^{+}$channels were suppressed by duloxetine [210,211], fluoxetine [212], amitriptyline [210,212-218], desipramine and maprotiline [219]. TTX-sensitive $\mathrm{Na}^{+}$channels in bovine adrenal chromaffin cells were inhibited by amitriptyline $\left(\mathrm{IC}_{50}=0.0202 \mathrm{mM}\right)$, fluoxetine $(62 \%$ amplitude reduction at $0.02 \mathrm{mM})$, desiparmine $(50 \%$ at $0.02 \mathrm{mM})$ and trazodone (20\% at $0.1 \mathrm{mM}$; [212]); amitriptyline also inhibited $\mathrm{Na}^{+}$channels in rat clonal pituitary $\mathrm{GH}_{3}$ cells with an $\mathrm{IC}_{50}$ value of $0.0398 \mathrm{mM}$ [204]. These efficacies in inhibiting $\mathrm{Na}^{+}$ channels were much larger than those of frog sciatic nerve CAPs. Furthermore, $\mathrm{IC}_{50}$ value $(0.0221 \mathrm{mM})$ for duloxetine to reduce (TTX-sensitive) Nav1.7 channel current amplitudes was about 10-fold less than that $(0.23 \mathrm{mM})$ for frog sciatic nerve CAP inhibition [211], but the efficacy sequence for CAP inhibition (maprotiline $>$ fluoxetine) was the same as that of the Nav1.7 channel, where $\mathrm{IC}_{50}$ values for maprotiline, fluoxetine, desipramine and amitriptyline were $0.028,0.074,0.024$ and $0.085 \mathrm{mM}$, respectively [219]. The observation that amitriptyline and duloxetine had a comparable $\mathrm{IC}_{50}$ value for frog sciatic nerve CAP inhibition was the same as that for cardiac-type $\mathrm{Na}^{+}$-channel inhibition [210]. TTX-resistant $\mathrm{Na}^{+}$channels (possibly Nav1.8 channels) in rat trigeminal ganglion neurons were also inhibited by amitriptyrine with an $\mathrm{IC}_{50}$ value of $0.00682 \mathrm{mM}$ [220]. Typical local anesthetics have hydrophobic and hydrophilic moieties that are separated by an intermediate ester or amide linkage (see [221] for review), while all of the antidepressants tested in the frog sciatic nerve, except for trazodone, have a hydrophilic amine group and a hydrophobic moiety containing benzene rings, both of which are linked by a straight chain hydrocarbon, in their chemical structures (see Figure 1 in [24] for the chemical structures of six antidepressants tested). Such chemical structures may take an important role in $\mathrm{Na}^{+}$channel inhibition. Table 5 summarizes $\mathrm{IC}_{50}$ values for frog sciatic nerve fast-conducting CAP inhibitions produced by antidepressants together with those for voltage-gated $\mathrm{Na}^{+}$channels.

Table 5. Comparison of $\mathrm{IC}_{50}$ values in inhibiting frog sciatic nerve fast-conducting CAPs and TTX-sensitive or -resistant $\mathrm{Na}^{+}$channels among antidepressants.

\begin{tabular}{|c|c|c|c|c|}
\hline Antidepressants & $\begin{array}{l}\text { Frog CAP } \\
\mathrm{IC}_{50}(\mathrm{mM})\end{array}$ & $\begin{array}{c}\text { TTX-Sensitive } \\
\mathrm{Na}^{+} \text {Channel } \\
\text { Current } \\
\mathrm{IC}_{50}(\mathrm{mM})\end{array}$ & $\begin{array}{c}\text { TTX-Resistant } \\
\mathrm{Na}^{+} \text {Channel } \\
\text { Current } \\
\mathrm{IC}_{50}(\mathrm{mM})\end{array}$ & References \\
\hline Duloxetine & 0.23 & 0.0221 & & {$[24,211]$} \\
\hline Fluoxetine & 1.5 & $\begin{array}{c}0.074 \\
62 \% \text { reduction }(0.02 \mathrm{mM})\end{array}$ & & $\begin{array}{c}{[24,219]} \\
{[212]}\end{array}$ \\
\hline Amitriptyline & 0.26 & $\begin{array}{c}0.0202 \\
0.0398 \\
0.085\end{array}$ & 0.00682 & $\begin{array}{c}{[24,212,220]} \\
{[204]} \\
{[219]}\end{array}$ \\
\hline Desipramine & 1.6 & $\begin{array}{c}0.024 \\
50 \% \text { reduction }(0.02 \mathrm{mM})\end{array}$ & & $\begin{array}{c}{[24,219]} \\
{[212]}\end{array}$ \\
\hline Maprotiline & 0.95 & 0.028 & & {$[24,219]$} \\
\hline Trazodone & ca. 1.0 & $20 \%$ reduction $(0.1 \mathrm{mM})$ & & {$[24,212]$} \\
\hline
\end{tabular}

The antidepressants tested are clinically used to treat chronic pain $[8,9,198,200,203,222,223]$ and inhibit neuropathic pain in animal models. For instance, duloxetine suppressed tactile allodynia and heat hyperalgesia in neuropathic pain rat models [197]; fluoxetine produced antinociception in streptozotocin-induced diabetic neuropathic pain mouse models [185]; amitriptyline and desipramine 
were effective in alleviating pain in patients with diabetic neuropathy [184]; maprotiline depressed neuropathic pain produced by chronic constriction injury of the sciatic nerve in rats [224]; trazodone inhibited hyperalgesia in chronic constriction injury rat models [206]. The plasma concentrations of duloxetine, fluoxetine, amitriptyline, desipramine, maprotiline and trazodone used to clinically treat depression and neuropathic pain are, respectively, 0.09-0.3, 0.3-1.6, 0.36-0.90, 0.47-1.1, 0.72-1.4 and 2.2-4.3 $\mu \mathrm{M}[189,211]$, values much smaller than those of $\mathrm{IC}_{50}$ for frog sciatic nerve CAP inhibition.

\subsection{Local Anesthetics}

Local anesthetics have been used for the treatment of the neuropathic pain with an expectation of the inhibition of nerve AP conduction in animals [225,226] and humans [227-230], although other effects including neurotransmitter receptor and TRP channel activation are possibly involved in antinociception [231]. Many of local anesthetics reduce both voltage-gated $\mathrm{Na}^{+}$and $\mathrm{K}^{+}$channel current amplitudes ([71]; see [76,231,232] for reviews).

An amide-type local anesthetic lidocaine, which is known to block AP conduction [58-60,232], reversibly reduced the peak amplitude of frog sciatic nerve CAPs in a wide concentration range of 0.1 to $2 \mathrm{mM}$ with an $\mathrm{IC}_{50}$ value of $0.74 \mathrm{mM}$ [19]. This value was somewhat larger than that $(0.204 \mathrm{mM})$ for $\mathrm{Na}^{+}$-channel current amplitude reduction in Xenopus laevis sciatic nerve fibers [71]. Voltage-gated $\mathrm{K}^{+}$ channels in this preparation were also inhibited by lidocaine with an $\mathrm{IC}_{50}$ value $(1.118 \mathrm{mM})$ larger than that for $\mathrm{Na}^{+}$channels [71]. Rat TTX-resistant $\mathrm{Na}^{+}$channel was inhibited by lidocaine with an $\mathrm{IC}_{50}$ of $0.073 \mathrm{mM}$ [148], a value 10-fold lower than that for frog sciatic nerve CAP inhibition.

A similar reversible CAP inhibition was produced by another amide-type local anesthetic ropivacaine, which has a longer duration of action in terms of nerve AP conduction block than lidocaine does ([233]; see [234] for review), in a concentration range of $0.01-1 \mathrm{mM}$ with an $\mathrm{IC}_{50}$ value of $0.34 \mathrm{mM}$ [19]. CAP peak amplitude reduction produced by ropivacaine in the frog sciatic nerve was almost similar in extent to that (about 30\% at $0.2 \mathrm{mM}$ ) reported for rabbit vagus nerve A fibers [235]. $\mathrm{IC}_{50}$ values for lidocaine and ropivacaine $(0.74$ and $0.34 \mathrm{mM}$, respectively) in the frog sciatic nerve were not so different from those $(0.28 \mathrm{mM}$ for both lidocaine and ropivacaine) for fast-conducting CAPs in the rat sciatic nerve [236]. Moreover, an amide-type local anesthetic prilocaine also reversibly reduced frog sciatic nerve CAP peak amplitudes; this activity was concentration-dependent in a range of $0.01-5 \mathrm{mM}$ with an $\mathrm{IC}_{50}$ value of $1.8 \mathrm{mM}$ [26].

Levobupivacaine and its racemic bupivacaine are amide-type local anesthetics; the former has a lower risk of cardiovascular and CNS toxicity than the latter ([237]; see [238] for review). Levobupivacaine reversibly reduced frog sciatic nerve CAP peak amplitudes in a concentration range of 0.05-1 $\mathrm{mM}$ with an $\mathrm{IC}_{50}$ value of $0.23 \mathrm{mM}$ [23]. This value was almost comparable to $\mathrm{IC}_{50}$ value $(0.22 \mathrm{mM})$ reported previously for tonic inhibition of frog sciatic nerve CAPs by levobupivacaine [237] and to that $(0.264 \mathrm{mM})$ for tonic inhibition by this drug of voltage-gated $\mathrm{Na}^{+}$-channel currents recorded at $-100 \mathrm{mV}$ in GH-3 neuroendocrine cells [239]. As reported previously [237], the levobupivacaine activity in the frog sciatic nerve was smaller than that of bupivacaine (CAP amplitude reductions at $0.5 \mathrm{mM}: 45$ and $76 \%$, respectively; [23]). This bupivacaine activity was smaller than that $\left(\mathrm{IC}_{50}=0.027 \mathrm{mM}\right)$ for $\mathrm{Na}^{+}$-channel current amplitude reduction in Xenopus laevis sciatic nerve fibers [71], that $\left(\mathrm{IC}_{50}=0.178 \mathrm{mM}\right)$ for TTX-sensitive $\mathrm{Na}^{+}$channels in DRG neuroblastoma hybridoma cell line ND7/23 cells [155] and that $\left(\mathrm{IC}_{50}=0.190 \mathrm{mM}\right)$ for $\mathrm{Na}^{+}$channels in rat clonal pituitary $\mathrm{GH}_{3}$ cells [204]. Voltage-gated $\mathrm{K}^{+}$channels in Xenopus laevis sciatic nerve fibers were also inhibited by bupivacaine with an $\mathrm{IC}_{50}$ value $(0.092 \mathrm{mM})$ larger than that for $\mathrm{Na}^{+}$channels [71].

Cocaine, a compound derived from the coca plant Erythroxylon coca, is a classic ester-type local anesthetic which is well-known to inhibit nerve AP conduction ([68,240,241]; see [242] for review). Cocaine reversibly reduced frog sciatic nerve CAP peak amplitudes in a reversible manner. This cocaine activity was concentration-dependent in a range of $0.01-2 \mathrm{mM}$ with an $\mathrm{IC}_{50}$ of $0.80 \mathrm{mM}$ [20], a value almost comparable to that $(0.74 \mathrm{mM})$ of lidocaine in the frog sciatic nerve [19]. The $\mathrm{IC}_{50}$ value for cocaine was 4 -fold larger than that (about $0.2 \mathrm{mM}$ ) in the rat phrenic nerve [68]. Although mouse 
phrenic CAP peak amplitudes were reduced by $26 \%$ by cocaine ( $40 \mu \mathrm{M}$ [241]), such a reduction in the frog sciatic nerve was produced at a concentration of about $300 \mu \mathrm{M}$ [20]. When compared between the frog and rat sciatic nerve, there was an almost similar CAP amplitude reduction by cocaine (frog: $30 \%$ at $0.5 \mathrm{mM}$; rat: $40 \%$ at $0.375 \mathrm{mM}$; see [72]). Much evidence shows an inhibition of voltage-gated $\mathrm{Na}^{+}$channels by cocaine (for example, see $[72,243,244]$ ), where a tonic (TTX-resistant) Nav1.5 channel current amplitude reduction produced by cocaine $(0.05 \mathrm{mM})$ is ca. $70 \%$ [244]. Cocaine and lidocaine exhibit a competitive interaction at $\mathrm{Na}^{+}$channels [245]. Cocaine is reported to also depress delayed rectifier $\mathrm{K}^{+}$channels in central snail neurons [246].

A well-known another ester-type local anesthetic procaine [247] reversibly reduced frog sciatic nerve CAP peak amplitudes in a concentration range of $0.1-5 \mathrm{mM}$ with an $\mathrm{IC}_{50}$ value of $2.2 \mathrm{mM}$ [27]. This value was almost comparable to those $(2-5 \mathrm{mM})$ obtained by other investigators $[248,249]$ in the same preparation and also to that (ca. $1 \mathrm{mM}$ ) reported previously in the rat sciatic nerve [248]. Moreover, a ratio of the procaine's $\mathrm{IC}_{50}$ value to that of lidocaine $(0.74 \mathrm{mM}$; [19]) for frog CAP inhibition was comparable to a ratio of procaine concentration $(0.53 \%)$, needed for $50 \%$ motor nerve conduction block, to lidocaine's one $(0.14 \%)$ in rats [250]. On the other hand, the frog sciatic nerve procaine activity was 37-fold smaller than that $\left(\mathrm{IC}_{50}=0.060 \mathrm{mM}\right)$ for $\mathrm{Na}^{+}$-channel current amplitude reduction in Xenopus laevis sciatic nerve fibers [71]. Voltage-gated $\mathrm{K}^{+}$channels in this preparation were also inhibited by procaine with an $\mathrm{IC}_{50}$ value $(6.303 \mathrm{mM})$ larger than that for $\mathrm{Na}^{+}$channels [71].

An ester-type local anesthetic benzocaine (ethyl 4-aminobenzoate) is used for topical anesthesia in clinical medicine (see [251] for review) and also for amphibian anesthesia ([252]; see [253,254] for reviews). Benzocaine reversibly reduced frog sciatic nerve CAP peak amplitudes; this activity was concentration-dependent in a range of $0.01-2 \mathrm{mM}$ with an $\mathrm{IC}_{50}$ value of $0.80 \mathrm{mM}(73 \%$ reduction at $1 \mathrm{mM}$; [25]). This activity was similar to that for CAP inhibition in the rat sciatic nerve ( $37 \%$ inhibition at $1.3 \mathrm{mM}$; [59]). When compared with other local anesthetics, benzocaine activity was similar to those of cocaine and lidocaine.

Frog CAP peak amplitude was reduced by an ester-type local anesthetic tetracaine in a reversible and concentration-dependent manner with an $\mathrm{IC}_{50}$ value of $0.014 \mathrm{mM}$. This value is not so distinct from that $(0.0063 \mathrm{mM})$ of frog sciatic nerve fibers, as reported previously [144], and also from that $(0.009 \mathrm{mM})$ of rabbit A nerve fibers [255]. On the other hand, the frog sciatic nerve tetracaine activity was 19-fold smaller than that $\left(\mathrm{IC}_{50}=0.0007 \mathrm{mM}\right)$ for $\mathrm{Na}^{+}$-channel current reduction in Xenopus laevis sciatic nerve fibers [71]. Voltage-gated $\mathrm{K}^{+}$channels in this preparation were also inhibited by tetracaine with an $\mathrm{IC}_{50}$ value $(0.946 \mathrm{mM})$ much larger than that for $\mathrm{Na}^{+}$channels [71]. Tetracaine had much more effectiveness than lidocaine, bupivacaine and procaine in both frog CAP and Xenopus laevis $\mathrm{Na}^{+}$-channel current inhibition.

A non-amide- and non-ester-type local anesthetic pramoxine also reduced frog sciatic nerve CAP peak amplitudes with a slow recovery to those before its application. This pramoxine activity was concentration-dependent in a range of $0.001-1 \mathrm{mM}$ with an $\mathrm{IC}_{50}$ value of $0.21 \mathrm{mM}$ [26]. Table 6 summarizes $\mathrm{IC}_{50}$ values for frog sciatic nerve fast-conducting $\mathrm{CAP}$ inhibitions produced by local anesthetics together with those for rat sciatic nerve CAPs and voltage-gated $\mathrm{Na}^{+}$channels. The chemical structures of local anesthetics tested are shown in Figure 4 in [25]. 
Table 6. Comparison of $\mathrm{IC}_{50}$ values in inhibiting frog or rat sciatic nerve fast-conducting CAPs and TTX-sensitive or -resistant $\mathrm{Na}^{+}$channels among local anesthetics.

\begin{tabular}{|c|c|c|c|c|c|}
\hline $\begin{array}{c}\text { Local } \\
\text { Anesthetics }\end{array}$ & $\begin{array}{c}\text { Frog } \\
\text { CAP } \\
\mathrm{IC}_{50}(\mathrm{mM})\end{array}$ & $\begin{array}{c}\text { Rat } \\
\text { CAP } \\
\mathrm{IC}_{50}(\mathrm{mM})\end{array}$ & $\begin{array}{c}\text { TTX-Sensitive } \\
\mathrm{Na}^{+} \text {Channel } \\
\text { Current } \\
\text { IC }_{50}(\mathrm{mM})\end{array}$ & $\begin{array}{c}\text { TTX-Resistant } \\
\mathrm{Na}^{+} \text {Channel } \\
\text { Current } \\
\mathrm{IC}_{50}(\mathrm{mM})\end{array}$ & References \\
\hline \multicolumn{6}{|l|}{ Amide Type } \\
\hline Lidocaine & 0.74 & 0.28 & 0.204 & 0.073 & {$[19,71,148,236]$} \\
\hline Ropivacaine & 0.34 & 0.28 & & & {$[19,236]$} \\
\hline Prilocaine & 1.8 & & & & [26] \\
\hline Levobupivacaine & 0.23 & & 0.264 & & {$[23,239]$} \\
\hline \multirow{3}{*}{ Bupivacaine } & $\begin{array}{c}76 \% \text { reduction } \\
(0.5 \mathrm{mM})\end{array}$ & & 0.027 & & {$[23,71]$} \\
\hline & & & 0.178 & & [155] \\
\hline & & & 0.190 & & [204] \\
\hline
\end{tabular}

\begin{tabular}{ccccc}
\hline Ester Type & \multicolumn{3}{c}{} & \\
Cocaine & 0.80 & $\begin{array}{c}40 \% \text { reduction } \\
(0.375 \mathrm{mM})\end{array}$ & $\begin{array}{c}\text { ca. } 70 \% \\
\text { reduction } \\
(0.05 \mathrm{mM})\end{array}$ & {$[20,72,244]$} \\
Procaine & 2.2 & ca. $1 \mathrm{mM}$ & 0.060 & {$[27,71,248]$} \\
\cline { 2 - 5 } Benzocaine & 0.80 & $\begin{array}{c}37 \% \text { reduction } \\
(1.3 \mathrm{mM})\end{array}$ & {$[25,59]$} \\
Tyyy & 0.014 & & 0.0007 & {$[22,71]$} \\
\hline Other Type & & & {$[26]$} \\
\hline Pramoxine & 0.21 & & & \\
\hline
\end{tabular}

Here, when $\mathrm{IC}_{50}$ values are not available, it is partly shown for comparison how CAP and channel current amplitudes are reduced by drugs, where $\%$ value indicates the extent of the reduction at the concentration shown in parentheses.

\section{Comparison in the Efficacy of Nerve Conduction Inhibition among Analgesics and Analgesic Adjuvants}

Some of analgesic adjuvants inhibited frog sciatic nerve CAPs with similar $\mathrm{IC}_{50}$ values. For instance, antidepressants' $\mathrm{IC}_{50}$ values were similar to those of some of antiepileptics, $\alpha_{2}$-adrenoceptor agonists and local anesthetics. Duloxetine and amitriptyline values $(0.23$ and $0.26 \mathrm{mM}$, respectively; see Table 5) were close to those of lamotrigine, carbamazepine, DEX, ropivacaine, levobupivacaine and pramoxine $(0.44,0.50,0.40,0.34,0.23$ and $0.21 \mathrm{mM}$, respectively; Tables 3,4 and 6$)$. On the other hand, fluoxetine, desipramine, maprotiline and trazodone values $(1.5,1.6,0.95$ and ca. $1 \mathrm{mM}$, respectively; Table 5) were similar to those of oxymetazoline, lidocaine, cocaine, procaine and prilocaine $(1.5,0.74,0.80,2.2$ and $1.8 \mathrm{mM}$, respectively; Tables 3 and 6). In each of the former ( $\left.\mathrm{IC}_{50}: 0.2-0.5 \mathrm{mM}\right)$ and latter $\left(\mathrm{IC}_{50}\right.$ : 1-2 $\mathrm{mM}$ ) groups, a chemical structure common among many drugs was not noted, although there was a relationship between CAP inhibition extent and the number of $\mathrm{CH}_{2}$ in opioids having similar structures, as mentioned in Section 2.1. The $\mathrm{IC}_{50}$ values of the antidepressants were much larger than that of tetracaine $(0.014 \mathrm{mM}$; Table 6$)$. Thus, some of the analgesic adjuvants will have an ability to inhibit nerve conduction with an efficacy comparable to each other.

When antipyretic analgesics NSAIDs were compared with analgesic adjuvants, diclofenac's $\mathrm{IC}_{50}$ value $(0.94 \mathrm{mM}$; Table 2$)$ was similar to those of maprotiline, trazodon, lidocaine and cocaine $(0.95$, ca. 1 , 0.74 and $0.80 \mathrm{mM}$, respectively; Tables 5 and 6), while aceclofenac, tolfenamic acid, meclofenamic acid and flufenamic acid $(0.47,0.29,0.19$ and $0.22 \mathrm{mM}$, respectively; Table 2$)$ had $\mathrm{IC}_{50}$ values being close to those of duloxetine, amitriptyline, lamotrigine, carbamazepine, DEX, ropivacaine, levobupivacaine and pramoxine $(0.23,0.26,0.44,0.50,0.40,0.34,0.23$ and $0.21 \mathrm{mM}$, respectively; Tables 3-6). The NSAIDs' values were smaller than those of fluoxetine, desipramine, oxymetazoline, procaine and prilocaine 
$(1.5,1.6,1.5,2.2$ and $1.8 \mathrm{mM}$, respectively; Tables 3,5 and 6$)$ while being larger than that of tetracaine (0.014 mM; Table 6). Thus, NSAIDs could inhibit nerve AP conduction with efficacies comparable to some of analgesic adjuvants. In these cases also, no common chemical structure was found among compounds with similar $\mathrm{IC}_{50}$ values.

Not only analgesic adjuvants and NSAIDs but also narcotic analgesics opioids have an ability to depress nerve AP conduction. Opioids reduced frog sciatic nerve CAP peak amplitudes; morphine and codeine at $5 \mathrm{mM}$ reduced CAP peak amplitude by $15 \%$ and $30 \%$, respectively, and tramadol and ethylmorphine had the $\mathrm{IC}_{50}$ values of 2.3 and $4.6 \mathrm{mM}$, respectively (Table 1). These opioid actions were smaller in magnitude than those of analgesic adjuvants and NASIDs. For example, the tramadol's $\mathrm{IC}_{50}$ value $(2.3 \mathrm{mM})$ was larger by 3.1- and 6.8 -fold than those $(0.74 \mathrm{mM}$ and $0.34 \mathrm{mM}$, respectively) of lidocaine and ropivacaine, respectively [19]. It has been previously reported that lidocaine reduces frog sciatic nerve CAP amplitudes with an $\mathrm{IC}_{50}$ of $6.6 \mathrm{mM} \mathrm{[60],} \mathrm{a} \mathrm{value} \mathrm{larger} \mathrm{by} \mathrm{three-fold} \mathrm{than}$ the tramadol value. However, ratio of the $\mathrm{IC}_{50}$ value of tramadol to that of lidocaine was almost comparable to Katsuki et al. [19]'s one, albeit $\mathrm{IC}_{50}$ values for lidocaine were largely distinct between the two studies $[19,60]$. A contribution of nerve AP conduction suppression to analgesia produced by opioids appears to be much less in extent compared to other well-known cellular mechanisms such as a decrease in the release of L-glutamate from nerve terminals and a membrane hyperpolarization in the spinal dorsal horn (for example, see $[28,29]$ ). Thus, nerve AP conduction inhibition may be a common mechanism for antinociception induced by analgesic adjuvants and NSAIDs but not opioids.

$\mathrm{IC}_{50}$ values for analgesic adjuvants in frog sciatic nerve CAPs were comparable in local anesthetic sensitivity to those in rat sciatic nerve CAPs while being generally larger than $\mathrm{IC}_{50}$ values for TTX-sensitive $\mathrm{Na}^{+}$channel currents. There are several possibilities for this difference. First, not only voltage-gated $\mathrm{Na}^{+}$but also $\mathrm{K}^{+}$channels are involved in the production of the CAP. Second, there may be a difference in expressed TTX-sensitive $\mathrm{Na}^{+}$-channel types (Nav1.1-1.4, Nav1.6 and Nav1.7) among the preparations examined. Third, CAPs are measured from the bundle of nerve fibers while $\mathrm{Na}^{+}$ currents from single cells. Since the analgesic adjuvants used clinically act on the nerve trunk and nerve conduction is mediated by both voltage-gated $\mathrm{Na}^{+}$and $\mathrm{K}^{+}$channels, their sciatic nerve $\mathrm{IC}_{50}$ values may be an appropriate measure for a nerve conduction inhibition in vivo. Considering that nociceptor-specific deletion of TTX-sensitive Nav1.7 gene results in attenuated acute and inflammatory hyperalgesia in mice [256], $\mathrm{Na}^{+}$channels may be the main target of analgesic adjuvants.

\section{Antinociceptive Plant-Derived Compounds Inhibit Nerve Conduction with Efficacies Comparable with Those of Analgesic Adjuvants and NSAIDs}

CAP inhibitory actions similar to those of analgesic adjuvants and NSAIDs were seen by plant-derived compounds that are known to produce antinociception by their oral, intraperitoneal or intrathecal administration (see $[257,258]$ for reviews). Thus, frog sciatic nerve CAPs were inhibited by plant-derived compounds whose $\mathrm{IC}_{50}$ values were close to those of analgesic adjuvants and NSAIDs ([27,259-261]; see [262] for review). Carvacrol, thymol, citronellol, bornyl acetate, citral, citronellal and geranyl acetate had $\mathrm{IC}_{50}$ values of $0.34,0.34,0.35,0.44,0.46,0.50$ and $0.51 \mathrm{mM}$, respectively, in reducing CAP peak amplitudes. These values were similar to those of duloxetine $(0.23 \mathrm{mM})$, amitriptyline $(0.26 \mathrm{mM})$, aceclofenac $(0.47 \mathrm{mM})$, tolfenamic acid $(0.29 \mathrm{mM})$, meclofenamic acid $(0.19 \mathrm{mM})$ and flufenamic acid $(0.22 \mathrm{mM}$; see Tables 2 and 5$)$. On the other hand, $\mathrm{IC}_{50}$ values of (+)-pulegone, (-)-carvone, (+)-borneol, (-)-menthone, cinnamaldehyde and allyl isothiocyanate $(1.4,1.4,1.5,1.5,1.2$ and $1.5 \mathrm{mM}$, respectively) were comparable to those of fluoxetine $(1.5 \mathrm{mM})$ and desipramine $\left(1.6 \mathrm{mM}\right.$; Table 5). $\mathrm{IC}_{50}$ values for diclofenac, maprotiline and trazodone $(0.94,0.95$ and ca. $1.0 \mathrm{mM}$, respectively; Tables 2 and 5) were close to those of linalyl acetate, eugenol and (-)-menthol $(0.71,0.81$ and $1.1 \mathrm{mM}$, respectively). Such CAP inhibitions produced by plant-derived compounds are possibly due to a suppression of TTX-sensitive voltage-gated $\mathrm{Na}^{+}$channels (for example, [263-266]; see [267] for review). Altogether, plant-derived chemicals could replace analgesic adjuvants and NSAIDs in terms of nerve AP conduction inhibition. 
Frog sciatic nerve CAPs were inhibited by a seven-membered ring compound hinokitiol ( $\beta$-thujaplicin; 2-hydroxy-4-isopropylcyclohepta-2,4,6-trien-1-one) contained in a species of cypress tree [268] with an $\mathrm{IC}_{50}$ of $0.54 \mathrm{mM}$, a value comparable to those of many plant-derived compounds. This inhibition was possibly due to an interaction involving its carbonyl, isopropyl and hydroxyl groups [269]. This carbonyl bond of hinokitiol serves for its seven-membered ring to act as a benzene ring, while the isopropyl and hydroxyl groups are important for the hinokitiol-induced CAP inhibition. Consistent with this idea, benzene-ring compounds having the isopropyl and hydroxyl groups, such as thymol, carvacrol, biosol (a stereoisomer of thymol and carvacrol; $\mathrm{IC}_{50}$ $=0.58 \mathrm{mM})$ and 4-isopropylphenol $(0.85 \mathrm{mM})$, had an ability to inhibit frog sciatic nerve CAPs (see above; $[259,269]$ ). Hinokitiol exhibits various actions such as inhibition of apoptosis [270], anti-bacterial, anti-inflammatory [271], insecticidal [272], anti-fungal [273], anti-tumor [274] and cytotoxic activities $[275,276]$. Hinokitiol used as a dermatological drug to suppress inflammation may exhibit a local anesthetic effect. Administration of an oral care gel containing hinokitiol to the oral mucosa reportedly alleviated oral pain in patients with oral lichen planus associated with hepatitis $C$ virus infection [277]. Such a pain alleviation may be partly due to a local anesthetic effect of hinokitiol.

Moreover, a general anesthetic propofol (2,6-diisopropylphenol; [278-280]; see [281,282] for reviews) having two isopropyl groups and one hydroxyl group bound to the benzene ring was found to concentration-dependently inhibit frog sciatic nerve CAPs with an $\mathrm{IC}_{50}$ value of $0.14 \mathrm{mM}$ [25]. Consistent with this result, propofol is reported to inhibit APs recorded extracellularly in the human and mammalian CNS [283,284].

Traditional Japanese (Kampo) medicines that are composed of plant-derived crude drugs are used together with Western medicines in Japan with various purposes including antinociception (see [285-289] for reviews). Frog sciatic nerve CAPs were concentration-dependently inhibited by Kampo medicines, daikenchuto, rikkosan, kikyoto, rikkunshito, shakuyakukanzoto and kakkonto; among them, daikenchuto was the most effective with an $\mathrm{IC}_{50}$ value of $1.1 \mathrm{mg} / \mathrm{mL}$. With respect to the activities of three kinds of crude medicine contained in daikenchuto, CAPs were inhibited by Japanese pepper and processed ginger while being hardly affected by ginseng radix. Japanese pepper's $\mathrm{IC}_{50}$ value was $0.77 \mathrm{mg} / \mathrm{mL}$ and the extent of CAP peak amplitude reduction produced by processed ginger at $2 \mathrm{mg} / \mathrm{mL}$ was 31\% [290]. At least a part of Kampo medicine's antinociceptive effect could attribute to its nerve AP conduction inhibitory action.

\section{Conclusions}

This review article demonstrated that some of NSAIDs, analgesic adjuvants and plant-derived compounds having analgesic activities inhibit frog sciatic nerve CAPs with similar efficacies. Although the CAPs are fast-conducting TTX-sensitive A $\alpha$ fiber-mediated ones, nociceptive information is transmitted by slow-conducting $A \delta$ and $C$ fibers [1]. In the frog sciatic nerve, $A \delta$-fiber CAPs were not able to be isolated from $A \alpha$-fiber ones; $C$-fiber CAPs were much smaller in peak amplitude and conduction velocity than fast-conducting ones [18] and thus were not able to be recorded. Therefore, the effects of the antinociceptive drugs on slow-conducting CAPs were not examined. In order to more elucidate a difference in the extent of nerve AP conduction inhibition among various antinociceptive drugs, it would be necessary to investigate their effects on slow-conducting CAPs.

In preparations other than the frog sciatic nerve, antinociceptive drugs are reported to inhibit not only A-fiber but also C-fiber CAPs. For example, in the rabbit vagus nerve, fentanyl and sufentanil reduced C-fiber CAP amplitudes with extents smaller than those of A-fiber ones [39] and lidocaine blocked nerve conduction in not only myelinated A- but also unmyelinated C-fibers ([291]; A-fiber CAPs were more sensitive to lidocaine than C-fiber's ones in rats, [292]). Clonidine inhibited both $\mathrm{A} \alpha$-fiber and C-fiber CAPs (see Section 3.1). Moreover, many investigators have reported an inhibition by lidocaine, $\alpha_{2}$-adrenoceptor agonists [148] and NSAIDs $[108,115,293]$ of TTX-resistant voltage-gated $\mathrm{Na}^{+}$channels (see Tables 2, 3 and 5) that may be involved in producing slow-conducting CAPs. It has 
been reported that the knockdown of TTX-resistant Nav1.8 channels results in inhibition of neuropathic and inflammatory pain in rats [294].

Since the concentrations of analgesics and analgesic adjuvants necessary to inhibit CAPs are higher than their clinically relevant ones, as mentioned in the previous sections, nerve conduction inhibition may occur when the drugs is administrated locally or is accumulated in the nervous system. If such an inhibition occurs in A $\alpha$ fibers innervating skeletal muscle, this would result in undesirable side effects such as muscle paralysis. $\mathrm{C}$ and $\mathrm{A} \delta$ fibers are smaller in diameter than $\mathrm{A} \alpha$ ones; therefore, if the drugs act on voltage-gated $\mathrm{Na}^{+}$channels from cytoplasm side, $\mathrm{C}$ fibers will precede $\mathrm{A} \alpha$ fibers in inhibiting nerve conduction owing to a difference in surface-to-volume ratio between the fibers. Thus, the drugs will have to be used at the lowest possible concentrations. It is suggested that at least a part of antinociception produced by analgesics and analgesic adjuvants is attributed to their inhibitory actions on nerve AP conduction mediated by voltage-gated $\mathrm{Na}^{+}$channels that are sensitive and resistant to TTX.

Funding: This research received no external funding.

Conflicts of Interest: The author declares no conflict of interest.

\section{References}

1. Fields, H.L. Pain; McGraw-Hill: New York, NY, USA, 1987.

2. Willis, W.D., Jr.; Coggeshall, R.E. Sensory Mechanisms of the Spinal Cord, 2nd ed.; Plenum: New York, NY, USA, 1991.

3. Merskey, H. Clarifying definition of neuropathic pain. Pain 2002, 96, 408-409. [CrossRef]

4. Amir, R.; Argoff, C.E.; Bennett, G.J.; Cummins, T.R.; Durieux, M.E.; Gerner, P.; Gold, M.S.; Porreca, F.; Strichartz, G.R. The role of sodium channels in chronic inflammatory and neuropathic pain. J. Pain 2006, 7, S1-S29. [CrossRef] [PubMed]

5. Finnerup, N.B.; Sindrup, S.H.; Jensen, T.S. The evidence for pharmacological treatment of neuropathic pain. Pain 2010, 150, 573-581. [CrossRef] [PubMed]

6. Jensen, T.S. Anticonvulsants in neuropathic pain: Rationale and clinical evidence. Eur. J. Pain 2002, 6 (Suppl. A), 61-68. [CrossRef] [PubMed]

7. Kamibayashi, T.; Maze, M. Clinical uses of $\alpha_{2}$-adrenergic agonists. Anesthesiology 2000, 93, 1345-1349. [CrossRef] [PubMed]

8. Lynch, M.E. Antidepressants as analgesics: A review of randomized controlled trials. J. Psychiatry Neurosci. 2001, 26, 30-36.

9. Sindrup, S.H.; Otto, M.; Finnerup, N.B.; Jensen, T.S. Antidepressants in the treatment of neuropathic pain. Basic Clin. Pharmacol. Toxicol. 2005, 96, 399-409. [CrossRef]

10. Theile, J.W.; Cummins, T.R. Recent developments regarding voltage-gated sodium channel blockers for the treatment of inherited and acquired neuropathic pain syndromes. Front. Pharmacol. 2011, 2, 54. [CrossRef]

11. Waszkielewicz, A.M.; Gunia, A.; Słoczyńska, K.; Marona, H. Evaluation of anticonvulsants for possible use in neuropathic pain. Curr. Med. Chem. 2011, 18, 4344-4358. [CrossRef]

12. Fürst, S. Transmitters involved in antinociception in the spinal cord. Brain Res. Bull. 1999, 48, 129-141. [CrossRef]

13. Kumamoto, E. Cellular mechanisms for antinociception produced by oxytocin and orexins in the rat spinal lamina II-Comparison with those of other endogenous pain modulators. Pharmaceuticals 2019, 12, 136. [CrossRef] [PubMed]

14. Zeilhofer, H.U.; Wildner, H.; Yévenes, G.E. Fast synaptic inhibition in spinal sensory processing and pain control. Physiol. Rev. 2012, 92, 193-235. [CrossRef] [PubMed]

15. Kiernan, M.C.; Bostock, H.; Park, S.B.; Kaji, R.; Krarup, C.; Krishnan, A.V.; Kuwabara, S.; Lin, C.S.; Misawa, S.; Moldovan, M.; et al. Measurement of axonal excitability: Consensus guidelines. Clin. Neurophysiol. 2020, 131, 308-323. [CrossRef] [PubMed]

16. Levitan, I.B.; Karczmarek, L.K. The Neuron, 3rd ed.; Oxford University Press: New York, NY, USA, 2002. 
17. Kumamoto, E.; Mizuta, K.; Fujita, T. Peripheral nervous system in the frog as a tool to examine the regulation of the transmission of neuronal information. In Frogs: Biology, Ecology and Uses; Murray, J.L., Ed.; Nova Science Publishers, Inc.: New York, NY, USA, 2012; pp. 89-106.

18. Kobayashi, J.; Ohta, M.; Terada, Y. C fiber generates a slow $\mathrm{Na}^{+}$spike in the frog sciatic nerve. Neurosci. Lett. 1993, 162, 93-96. [CrossRef]

19. Katsuki, R.; Fujita, T.; Koga, A.; Liu, T.; Nakatsuka, T.; Nakashima, M.; Kumamoto, E. Tramadol, but not its major metabolite (mono-O-demethyl tramadol) depresses compound action potentials in frog sciatic nerves. Br. J. Pharmacol. 2006, 149, 319-327. [CrossRef] [PubMed]

20. Mizuta, K.; Fujita, T.; Nakatsuka, T.; Kumamoto, E. Inhibitory effects of opioids on compound action potentials in frog sciatic nerves and their chemical structures. Life Sci. 2008, 83, 198-207. [CrossRef]

21. Suzuki, R.; Fujita, T.; Mizuta, K.; Kumamoto, E. Inhibition by non-steroidal anti-inflammatory drugs of compound action potentials in frog sciatic nerve fibers. Biomed. Pharmacother. 2018, 103, 326-335. [CrossRef]

22. Kosugi, T.; Mizuta, K.; Fujita, T.; Nakashima, M.; Kumamoto, E. High concentrations of dexmedetomidine inhibit compound action potentials in frog sciatic nerves without $\alpha_{2}$ adrenoceptor activation. Br. J. Pharmacol. 2010, 160, 1662-1676. [CrossRef]

23. Uemura, Y.; Fujita, T.; Ohtsubo, S.; Hirakawa, N.; Sakaguchi, Y.; Kumamoto, E. Effects of various antiepileptics used to alleviate neuropathic pain on compound action potential in frog sciatic nerves: Comparison with those of local anesthetics. Biomed. Res. Int. 2014, 2014, 540238. [CrossRef]

24. Hirao, R.; Fujita, T.; Sakai, A.; Kumamoto, E. Compound action potential inhibition produced by various antidepressants in the frog sciatic nerve. Eur. J. Pharmacol. 2018, 819, 122-128. [CrossRef]

25. Magori, N.; Fujita, T.; Mizuta, K.; Kumamoto, E. Inhibition by general anesthetic propofol of compound action potentials in the frog sciatic nerve and its chemical structure. Naunyn-Schmiedeberg's Arch. Pharmacol. 2019, 392, 359-369. [CrossRef] [PubMed]

26. Mizuta, K.; Fujita, T.; Yamagata, H.; Kumamoto, E. Bisphenol A inhibits compound action potentials in the frog sciatic nerve in a manner independent of estrogen receptors. Biochem. Biophys. Rep. 2017, 10, 145-151. [CrossRef] [PubMed]

27. Tomohiro, D.; Mizuta, K.; Fujita, T.; Nishikubo, Y.; Kumamoto, E. Inhibition by capsaicin and its related vanilloids of compound action potentials in frog sciatic nerves. Life Sci. 2013, 92, 368-378. [CrossRef] [PubMed]

28. Fujita, T.; Kumamoto, E. Inhibition by endomorphin-1 and endomorphin-2 of excitatory transmission in adult rat substantia gelatinosa neurons. Neuroscience 2006, 139, 1095-1105. [CrossRef] [PubMed]

29. Kohno, T.; Kumamoto, E.; Higashi, H.; Shimoji, K.; Yoshimura, M. Actions of opioids on excitatory and inhibitory transmission in substantia gelatinosa of adult rat spinal cord. J. Physiol. 1999, 518, 803-813. [CrossRef] [PubMed]

30. Yoshimura, M.; North, R.A. Substantia gelatinosa neurones hyperpolarized in vitro by enkephalin. Nature 1983, 305, 529-530. [CrossRef]

31. North, R.A. Opioid actions on membrane ion channels. In Handbook of Experimental Pharmacology; Herz, A., Ed.; Springer: Berlin, Germany, 1993; Volume 104, pp. 773-797.

32. Yaksh, T.L. Pharmacology and mechanisms of opioid analgesic activity. Acta Anaesthesiol. Scand. 1997, 41, 94-111. [CrossRef]

33. Labuz, D.; Mousa, S.A.; Schäfer, M.; Stein, C.; Machelska, H. Relative contribution of peripheral versus central opioid receptors to antinociception. Brain Res. 2007, 1160, 30-38. [CrossRef]

34. Shannon, H.E.; Lutz, E.A. Comparison of the peripheral and central effects of the opioid agonists loperamide and morphine in the formalin test in rats. Neuropharmacology 2002, 42, 253-261. [CrossRef]

35. Smith, T.W.; Buchan, P.; Parsons, D.N.; Wilkinson, S. Peripheral antinociceptive effects of N-methyl morphine. Life Sci. 1982, 31, 1205-1208. [CrossRef]

36. Wenk, H.N.; Brederson, J.-D.; Honda, C.N. Morphine directly inhibits nociceptors in inflamed skin. J. Neurophysiol. 2006, 95, 2083-2097. [CrossRef] [PubMed]

37. Stein, C.; Schäfer, M.; Machelska, H. Attacking pain at its source: New perspectives on opioids. Nature Med. 2003, 9, 1003-1008. [CrossRef] [PubMed]

38. Yuge, O.; Matsumoto, M.; Kitahata, L.M.; Collins, J.G.; Senami, M. Direct opioid application to peripheral nerves does not alter compound action potentials. Anesth. Analg. 1985, 64, 667-671. [CrossRef] 
39. Gissen, A.J.; Gugino, L.D.; Datta, S.; Miller, J.; Covino, B.G. Effects of fentanyl and sufentanil on peripheral mammalian nerves. Anesth. Analg. 1987, 66, 1272-1276. [CrossRef] [PubMed]

40. Jaffe, R.A.; Rowe, M.A. A comparison of the local anesthetic effects of meperidine, fentanyl, and sufentanil on dorsal root axons. Anesth. Analg. 1996, 83, 776-781. [CrossRef] [PubMed]

41. Jurna, I.; Grossmann, W. The effect of morphine on mammalian nerve fibres. Eur. J. Pharmacol. 1977, 44, 339-348. [CrossRef]

42. Coggeshall, R.E.; Zhou, S.; Carlton, S.M. Opioid receptors on peripheral sensory axons. Brain Res. 1997, 764, 126-132. [CrossRef]

43. Fields, H.L.; Emson, P.C.; Leigh, B.K.; Gilbert, R.F.T.; Iversen, L.L. Multiple opiate receptor sites on primary afferent fibres. Nature 1980, 284, 351-353. [CrossRef]

44. Wenk, H.N.; Honda, C.N. Immunohistochemical localization of delta opioid receptors in peripheral tissues. J. Comp. Neurol. 1999, 408, 567-579. [CrossRef]

45. Hunter, E.G.; Frank, G.B. An opiate receptor on frog sciatic nerve axons. Can. J. Physiol. Pharmacol. 1979, 57, 1171-1174. [CrossRef]

46. Klotz, U. Tramadol-The impact of its pharmacokinetic and pharmacodynamic properties on the clinical management of pain. Arzneimittelforschung 2003, 53, 681-687. [CrossRef] [PubMed]

47. Lintz, W.; Erlacin, S.; Frankus, E.; Uragg, H. Metabolismus von Tramadol bei Mensch und Tier. Arzneimittelforschung 1981, 31, 1932-1943. [PubMed]

48. Hennies, H.-H.; Friderichs, E.; Schneider, J. Receptor binding, analgesic and antitussive potency of tramadol and other selected opioids. Arzneimittelforschung 1988, 38, 877-880. [PubMed]

49. Raffa, R.B.; Friderichs, E.; Reimann, W.; Shank, R.P.; Codd, E.E.; Vaught, J.L. Opioid and nonopioid components independently contribute to the mechanism of action of tramadol, an 'atypical' opioid analgesic. J. Pharmacol. Exp. Ther. 1992, 260, 275-285. [PubMed]

50. Koga, A.; Fujita, T.; Totoki, T.; Kumamoto, E. Tramadol produces outward currents by activating $\mu$-opioid receptors in adult rat substantia gelatinosa neurones. Br. J. Pharmacol. 2005, 145, 602-607. [CrossRef] [PubMed]

51. Koga, A.; Fujita, T.; Piao, L.-H.; Nakatsuka, T.; Kumamoto, E. Inhibition by O-desmethyltramadol of glutamatergic excitatory transmission in adult rat spinal substantia gelatinosa neurons. Mol. Pain 2019, 15, 1744806918824243. [CrossRef]

52. Yamasaki, H.; Funai, Y.; Funao, T.; Mori, T.; Nishikawa, K. Effects of tramadol on substantia gelatinosa neurons in the rat spinal cord: An in vivo patch-clamp analysis. PLoS ONE 2015, 10, e0125147. [CrossRef]

53. Altunkaya, H.; Ozer, Y.; Kargi, E.; Babuccu, O. Comparison of local anaesthetic effects of tramadol with prilocaine for minor surgical procedures. Br. J. Anaesth. 2003, 90, 320-322. [CrossRef]

54. Altunkaya, H.; Ozer, Y.; Kargi, E.; Ozkocak, I.; Hosnuter, M.; Demirel, C.B.; Babuccu, O. The postoperative analgesic effect of tramadol when used as subcutaneous local anesthetic. Anesth. Analg. 2004, 99, 1461-1464. [CrossRef]

55. Pang, W.-W.; Mok, M.S.; Chang, D.-P.; Huang, M.-H. Local anesthetic effect of tramadol, metoclopramide, and lidocaine following intradermal injection. Reg. Anesth. Pain Med. 1998, 23, 580-583. [CrossRef]

56. Le Roux, P.J.; Coetzee, J.F. Tramadol today. Curr. Opin. Anaesth. 2000, 13, 457-461. [CrossRef] [PubMed]

57. Tsai, Y.-C.; Chang, P.-J.; Jou, I.-M. Direct tramadol application on sciatic nerve inhibits spinal somatosensory evoked potentials in rats. Anesth. Analg. 2001, 92, 1547-1551. [CrossRef] [PubMed]

58. Mert, T.; Gunes, Y.; Guven, M.; Gunay, I.; Ozcengiz, D. Comparison of nerve conduction blocks by an opioid and a local anesthetic. Eur. J. Pharmacol. 2002, 439, 77-81. [CrossRef]

59. Güven, M.; Mert, T.; Günay, I. Effects of tramadol on nerve action potentials in rat: Comparisons with benzocaine and lidocaine. Int. J. Neurosci. 2005, 115, 339-349. [CrossRef] [PubMed]

60. Mert, T.; Gunes, Y.; Guven, M.; Gunay, I.; Gocmen, C. Differential effects of lidocaine and tramadol on modified nerve impulse by 4-aminopyridine in rats. Pharmacology 2003, 69, 68-73. [CrossRef]

61. Gillen, C.; Haurand, M.; Kobelt, D.J.; Wnendt, S. Affinity, potency and efficacy of tramadol and its metabolites at the cloned human $\mu$-opioid receptor. Naunyn-Schmiedeberg's Arch. Pharmacol. 2000, 362, 116-121. [CrossRef]

62. Driessen, B.; Reimann, W. Interaction of the central analgesic, tramadol, with the uptake and release of 5-hydroxytryptamine in the rat brain in vitro. Br. J. Pharmacol. 1992, 105, 147-151. [CrossRef]

63. Driessen, B.; Reimann, W.; Giertz, H. Effects of the central analgesic tramadol on the uptake and release of noradrenaline and dopamine in vitro. Br. J. Pharmacol. 1993, 108, 806-811. [CrossRef] 
64. Leffler, A.; Frank, G.; Kistner, K.; Niedermirtl, F.; Koppert, W.; Reeh, P.W.; Nau, C. Local anesthetic-like inhibition of voltage-gated $\mathrm{Na}^{+}$channels by the partial $\mu$-opioid receptor agonist buprenorphine. Anesthesiology 2012, 116, 1335-1346. [CrossRef]

65. Haeseler, G.; Foadi, N.; Ahrens, J.; Dengler, R.; Hecker, H.; Leuwer, M. Tramadol, fentanyl and sufentanil but not morphine block voltage-operated sodium channels. Pain 2006, 126, 234-244. [CrossRef]

66. Tsai, T.-Y.; Tsai, Y.-C.; Wu, S.-N.; Liu, Y.-C. Tramadol-induced blockade of delayed rectifier potassium current in NG108-15 neuronal cells. Eur. J. Pain 2006, 10, 597-601. [CrossRef]

67. Grond, S.; Meuser, T.; Uragg, H.; Stahlberg, H.J.; Lehmann, K.A. Serum concentrations of tramadol enantiomers during patient-controlled analgesia. Br. J. Clin. Pharmacol. 1999, 48, 254-257. [CrossRef]

68. Brodin, P.; Skoglund, L.A. Dose-response inhibition of rat compound nerve action potential by dextropropoxyphene and codeine compared to morphine and cocaine in vitro. Gen. Pharmacol. 1990, 21, 551-553. [CrossRef]

69. Kumamoto, E.; Mizuta, K.; Fujita, T. Opioid actions in primary-afferent fibers-Involvement in analgesia and anesthesia. Pharmaceuticals 2011, 4, 343-365. [CrossRef]

70. Bräu, M.E.; Nau, C.; Hempelmann, G.; Vogel, W. Local anesthetics potently block a potential insensitive potassium channel in myelinated nerve. J. Gen. Physiol. 1995, 105, 485-505. [CrossRef]

71. Bräu, M.E.; Vogel, W.; Hempelmann, G. Fundamental properties of local anesthetics: Half-maximal blocking concentrations for tonic block of $\mathrm{Na}^{+}$and $\mathrm{K}^{+}$channels in peripheral nerve. Anesth. Analg. 1998, 87, 885-889.

72. Tokuno, H.A.; Bradberry, C.W.; Everill, B.; Agulian, S.K.; Wilkes, S.; Baldwin, R.M.; Tamagnan, G.D.; Kocsis, J.D. Local anesthetic effects of cocaethylene and isopropylcocaine on rat peripheral nerves. Brain Res. 2004, 996, 159-167. [CrossRef]

73. Chen, Z.R.; Irvine, R.J.; Somogyi, A.A.; Bochner, F. Mu receptor binding of some commonly used opioids and their metabolites. Life Sci. 1991, 48, 2165-2171. [CrossRef]

74. Mizuta, K.; Fujita, T.; Kumamoto, E. Inhibition by morphine and its analogs of action potentials in adult rat dorsal root ganglion neurons. J. Neurosci. Res. 2012, 90, 1830-1841. [CrossRef]

75. Staiman, A.; Seeman, P. The impulse-blocking concentrations of anesthetics, alcohols, anticonvulsants, barbiturates, and narcotics on phrenic and sciatic nerves. Can. J. Physiol. Pharmacol. 1974, 52, 535-550. [CrossRef]

76. Scholz, A. Mechanisms of (local) anaesthetics on voltage-gated sodium and other ion channels. Br. J. Anaesth. 2002, 89, 52-61. [CrossRef] [PubMed]

77. Hu, S.; Rubly, N. Effects of morphine on ionic currents in frog node of Ranvier. Eur. J. Pharmacol. 1983, 95, 185-192. [CrossRef]

78. Frazier, D.T.; Murayama, K.; Abbott, N.J.; Narahashi, T. Effects of morphine on internally perfused squid giant axons. Proc. Soc. Exp. Biol. Med. 1972, 139, 434-438. [CrossRef]

79. Wagner, L.E., II; Eaton, M.; Sabnis, S.S.; Gingrich, K.J. Meperidine and lidocaine block of recombinant voltage-dependent $\mathrm{Na}^{+}$channels: Evidence that meperidine is a local anesthetic. Anesthesiology 1999, 91, 1481-1490. [CrossRef]

80. Viel, E.J.; Eledjam, J.J.; De La Coussaye, J.E.; D'Athis, F. Brachial plexus block with opioids for postoperative pain relief: Comparison between buprenorphine and morphine. Reg. Anesth. 1989, 14, 274-278.

81. Gutstein, H.B.; Akil, H. Opioid analgesics. In Goodman \& Gilman's the Pharmacological Basis of Therapeutics, 11th ed.; Brunton, L.L., Lazo, J.S., Parker, K.L., Eds.; McGraw-Hill, Medical Publishing Division: New York, NY, USA, 2006; pp. 547-590.

82. King, M.; Su, W.; Chang, A.; Zuckerman, A.; Pasternak, G.W. Transport of opioids from the brain to the periphery by P-glycoprotein: Peripheral actions of central drugs. Nat. Neurosci. 2001, 4, 268-274. [CrossRef]

83. Stein, C.; Comisel, K.; Haimerl, E.; Yassouridis, A.; Lehrberger, K.; Herz, A.; Peter, K. Analgesic effect of intraarticular morphine after arthroscopic knee surgery. N. Engl. J. Med. 1991, 325, 1123-1126. [CrossRef]

84. Mays, K.S.; Lipman, J.J.; Schnapp, M. Local analgesia without anesthesia using peripheral perineural morphine injections. Anesth. Analg. 1987, 66, 417-420. [CrossRef]

85. Cleary, J.; Mikus, G.; Somogyi, A.; Bochner, F. The influence of pharmacogenetics on opioid analgesia: Studies with codeine and oxycodone in the Sprague-Dawley/Dark Agouti rat model. J. Pharmacol. Exp. Ther. 1994, 271, 1528-1534.

86. Mikus, G.; Somogyi, A.A.; Bochner, F.; Eichelbaum, M. Codeine O-demethylation: Rat strain differences and the effects of inhibitors. Biochem. Pharmacol. 1991, 41, 757-762. [CrossRef] 
87. Ferreira, S.H. Prostaglandins, aspirin-like drugs and analgesia. Nat. New Biol. 1972, 240, 200-203. [CrossRef]

88. Takayama, K.; Hirose, A.; Suda, I.; Miyazaki, A.; Oguchi, M.; Onotogi, M.; Fotopoulos, G. Comparison of the anti-inflammatory and analgesic effects in rats of diclofenac-sodium, felbinac and indomethacin patches. Int. J. Biomed. Sci. 2011, 7, 222-229.

89. Grosser, T.; Smyth, E.; FitzGerald, G.A. Anti-inflammatory, antipyretic, and analgesic agents; pharmacotherapy of gout. In Goodman \& Gilman's the Pharmacological Basis of Therapeutics, 12th ed.; Brunton, L.L., Chabner, B.A., Knollmann, B.C., Eds.; McGraw-Hill, Medical Publishing Division: New York, NY, USA, 2011; pp. 959-1004.

90. Simmons, D.L.; Botting, R.M.; Hla, T. Cyclooxygenase isozymes: The biology of prostaglandin synthesis and inhibition. Pharmacol. Rev. 1996, 56 (Suppl. 1), 387-437. [CrossRef]

91. Vane, J.R. Introduction: Mechanism of action of NSAIDs. Br. J. Rheumatol. 1996, 35 (Suppl. 1), 1-3. [CrossRef]

92. Voilley, N.; de Weille, J.; Mamet, J.; Lazdunski, M. Nonsteroid anti-inflammatory drugs inhibit both the activity and the inflammation-induced expression of acid-sensing ion channels in nociceptors. J. Neurosci. 2001, 21, 8026-8033. [CrossRef]

93. Inoue, N.; Ito, S.; Nogawa, M.; Tajima, K.; Kyoi, T. Etodolac blocks the allyl isothiocyanate-induced response in mouse sensory neurons by selective TRPA1 activation. Pharmacology 2012, 90, 47-54. [CrossRef]

94. Suzuki, H.; Sasaki, E.; Nakagawa, A.; Muraki, Y.; Hatano, N.; Muraki, K. Diclofenac, a nonsteroidal anti-inflammatory drug, is an antagonist of human TRPM3 isoforms. Pharmacol. Res. Perspect. 2016, 4, e00232. [CrossRef]

95. Garg, P.; Sanguinetti, M.C. Structure-activity relationship of fenamates as Slo2.1 channel activators. Mol. Pharmacol. 2012, 82, 795-802. [CrossRef]

96. Ortiz, M.I.; Torres-López, J.E.; Castañeda-Hernández, G.; Rosas, R.; Vidal-Cantú, G.C.; Granados-Soto, V. Pharmacological evidence for the activation of $\mathrm{K}^{+}$channels by diclofenac. Eur. J. Pharmacol. 2002, 438, 85-91. [CrossRef]

97. Ortiz, M.I.; Castañeda-Hernández, G.; Granados-Soto, V. Pharmacological evidence for the activation of $\mathrm{Ca}^{2+}$-activated $\mathrm{K}^{+}$channels by meloxicam in the formalin test. Pharmacol. Biochem. Behav. 2005, 81, 725-731. [CrossRef]

98. Ortiz, M.I.; Granados-Soto, V.; Castañeda-Hernández, G. The NO-cGMP-K ${ }^{+}$channel pathway participates in the antinociceptive effect of diclofenac, but not of indomethacin. Pharmacol. Biochem. Behav. 2003, 76, 187-195. [CrossRef]

99. Peretz, A.; Degani, N.; Nachman, R.; Uziyel, Y.; Gibor, G.; Shabat, D.; Attali, B. Meclofenamic acid and diclofenac, novel templates of KCNQ2/Q3 potassium channel openers, depress cortical neuron activity and exhibit anticonvulsant properties. Mol. Pharmacol. 2005, 67, 1053-1066. [CrossRef]

100. Guinamard, R.; Simard, C.; Del Negro, C. Flufenamic acid as an ion channel modulator. Pharmacol. Ther. 2013, 138, 272-284. [CrossRef]

101. Gwanyanya, A.; Macianskiene, R.; Mubagwa, K. Insights into the effects of diclofenac and other non-steroidal anti-inflammatory agents on ion channels. J. Pharm. Pharmacol. 2012, 64, 1359-1375. [CrossRef]

102. Papworth, J.; Colville-Nash, P.; Alam, C.; Seed, M.; Willoughby, D. The depletion of substance P by diclofenac in the mouse. Eur. J. Pharmacol. 1997, 325, R1-R2. [CrossRef]

103. Silva, L.C.R.; Castor, M.G.M.; Souza, T.C.; Duarte, I.D.G.; Romero, T.R.L. NSAIDs induce peripheral antinociception by interaction with the adrenergic system. Life Sci. 2015, 130, 7-11. [CrossRef]

104. Silva, L.C.R.; Castor, M.G.Me.; Navarro, L.C.; Romero, T.R.L.; Duarte, I.D.G. k-Opioid receptor participates of NSAIDs peripheral antinociception. Neurosci. Lett. 2016, 622, 6-9. [CrossRef]

105. Vazquez, E.; Hernandez, N.; Escobar, W.; Vanegas, H. Antinociception induced by intravenous dipyrone (metamizol) upon dorsal horn neurons: Involvement of endogenous opioids at the periaqueductal gray matter, the nucleus raphe magnus, and the spinal cord in rats. Brain Res. 2005, 1048, 211-217. [CrossRef]

106. Fowler, C.J. NSAIDs: eNdocannabinoid stimulating anti-inflammatory drugs? Trends Pharmacol. Sci. 2012, 33, 468-473. [CrossRef]

107. McCormack, K.; Brune, K. Dissociation between the antinociceptive and anti-inflammatory effects of the nonsteroidal anti-inflammatory drugs. A survey of their analgesic efficacy. Drugs 1991, 41, 533-547. [CrossRef]

108. Lee, H.M.; Kim, H.I.; Shin, Y.K.; Lee, C.S.; Park, M.; Song, J.-H. Diclofenac inhibition of sodium currents in rat dorsal root ganglion neurons. Brain Res. 2003, 992, 120-127. [CrossRef] [PubMed] 
109. Acosta, M.C.; Luna, C.; Graff, G.; Meseguer, V.M.; Viana, F.; Gallar, J.; Belmonte, C. Comparative effects of the nonsteroidal anti-inflammatory drug nepafenac on corneal sensory nerve fibers responding to chemical irritation. Investig. Ophthalmol. Vis. Sci. 2007, 48, 182-188. [CrossRef]

110. Fei, X.-W.; Liu, L.-Y.; Xu, J.-G.; Zhang, Z.-H.; Mei, Y.-A. The non-steroidal anti-inflammatory drug, diclofenac, inhibits $\mathrm{Na}^{+}$current in rat myoblasts. Biochem. Biophys. Res. Commun. 2006, 346, 1275-1283. [CrossRef] [PubMed]

111. Yarishkin, O.V.; Hwang, E.M.; Kim, D.; Yoo, J.C.; Kang, S.S.; Kim, D.R.; Shin, J.-H.-J.; Chung, H.-J.; Jeong, H.-S.; Kang, D.; et al. Diclofenac, a non-steroidal anti-inflammatory drug, inhibits L-type $\mathrm{Ca}^{2+}$ channels in neonatal rat ventricular cardiomyocytes. Korean J. Physiol. Pharmacol. 2009, 13, 437-442. [CrossRef]

112. Kuo, C.-C.; Huang, R.-C.; Lou, B.-S. Inhibition of $\mathrm{Na}^{+}$current by diphenhydramine and other diphenyl compounds: Molecular determinants of selective binding to the inactivated channels. Mol. Pharmacol. 2000, 57, 135-143. [PubMed]

113. Yang, Y.-C.; Kuo, C.-C. An inactivation stabilizer of the $\mathrm{Na}^{+}$channel acts as an opportunistic pore blocker modulated by external Na ${ }^{+}$. J. Gen. Physiol. 2005, 125, 465-481. [CrossRef] [PubMed]

114. Yau, H.-J.; Baranauskas, G.; Martina, M. Flufenamic acid decreases neuronal excitability through modulation of voltage-gated sodium channel gating. J. Physiol. 2010, 588, 3869-3882. [CrossRef] [PubMed]

115. Nakamura, M.; Jang, I.-S. pH-dependent inhibition of tetrodotoxin-resistant $\mathrm{Na}^{+}$channels by diclofenac in rat nociceptive neurons. Prog. Neuropsychopharmacol. Biol. Psychiatry 2016, 64, 35-43. [CrossRef] [PubMed]

116. Sun, J.-F.; Xu, Y.-J.; Kong, X.-H.; Su, Y.; Wang, Z.-Y. Fenamates inhibit human sodium channel Nav1.7 and Nav1.8. Neurosci. Lett. 2019, 696, 67-73. [CrossRef]

117. Chen, X.; Gallar, J.; Belmonte, C. Reduction by antiinflammatory drugs of the response of corneal sensory nerve fibers to chemical irritation. Investig. Ophthalmol. Vis. Sci. 1997, 38, 1944-1953.

118. Gil-Flores, M.; Ortiz, M.I.; Castañeda-Hernández, G.; Chávez-Piña, A.E. Acemetacin antinociceptive mechanism is not related to $\mathrm{NO}$ or $\mathrm{K}^{+}$channel pathways. Methods Find. Exp. Clin. Pharmacol. 2010, 32, 101-105. [CrossRef] [PubMed]

119. Gögelein, H.; Dahlem, D.; Englert, H.C.; Lang, H.J. Flufenamic acid, mefenamic acid and niflumic acid inhibit single nonselective cation channels in the rat exocrine pancreas. FEBS Lett. 1990, 268, 79-82. [CrossRef]

120. Hu, H.; Tian, J.; Zhu, Y.; Wang, C.; Xiao, R.; Herz, J.M.; Wood, J.D.; Zhu, M.X. Activation of TRPA1 channels by fenamate nonsteroidal anti-inflammatory drugs. Pflügers Arch. 2010, 459, 579-592. [CrossRef] [PubMed]

121. Tatematsu, Y.; Hayashi, H.; Taguchi, R.; Fujita, H.; Yamamoto, A.; Ohkura, K. Effect of N-phenylanthranilic acid scaffold nonsteroidal anti-inflammatory drugs on the mitochondrial permeability transition. Biol. Pharm. Bull. 2016, 39, 278-284. [CrossRef] [PubMed]

122. Glass, J.S.; Hardy, C.L.; Meeks, N.M.; Carroll, B.T. Acute pain management in dermatology: Risk assessment and treatment. J. Am. Acad. Dermatol. 2015, 73, 543-560. [CrossRef] [PubMed]

123. Bhana, N.; Goa, K.L.; McClellan, K.J. Dexmedetomidine. Drugs 2000, 59, 263-268. [CrossRef]

124. Costa-Pereira, J.T.; Ribeiro, J.; Martins, I.; Tavares, I. Role of spinal cord $\alpha_{2}$-adrenoreceptors in noradrenergic inhibition of nociceptive transmission during chemotherapy-induced peripheral neuropathy. Front. Neurosci. 2020, 13, 1413. [CrossRef]

125. Fisher, B.; Zornow, M.H.; Yaksh, T.L.; Peterson, B.M. Antinociceptive properties of intrathecal dexmedetomidine in rats. Eur. J. Pharmacol. 1991, 192, 221-225. [CrossRef]

126. Takano, Y.; Yaksh, T.L. Relative efficacy of spinal alpha-2 agonists, dexmedetomidine, clonidine and ST-91, determined in vivo by using N-ethoxycarbonyl-2-ethoxy-1,2-dihydroquinoline, an irreversible antagonist. J. Pharmacol. Exp. Ther. 1991, 258, 438-446.

127. Filos, K.S.; Goudas, L.C.; Patroni, O.; Polyzou, V. Hemodynamic and analgesic profile after intrathecal clonidine in humans. A dose-response study. Anesthesiology 1994, 81, 591-601. [CrossRef]

128. Sullivan, A.F.; Kalso, E.A.; McQuay, H.J.; Dickenson, A.H. The antinociceptive actions of dexmedetomidine on dorsal horn neuronal responses in the anaesthetized rat. Eur. J. Pharmacol. 1992, 215, 127-133. [CrossRef]

129. Brummett, C.M.; Norat, M.A.; Palmisano, J.M.; Lydic, R. Perineural administration of dexmedetomidine in combination with bupivacaine enhances sensory and motor blockade in sciatic nerve block without inducing neurotoxicity in rat. Anesthesiology 2008, 109, 502-511. [CrossRef] [PubMed]

130. Calasans-Maia, J.A.; Zapata-Sudo, G.; Sudo, R.T. Dexmedetomidine prolongs spinal anaesthesia induced by levobupivacaine $0.5 \%$ in guinea-pigs. J. Pharm. Pharmacol. 2005, 57, 1415-1420. [CrossRef] [PubMed] 
131. Mohyiedin, H.; Kamelia, A.A.; Ekram, F.S.; Al Shaimaa, A.K. The effect of various additives to local anesthetics on the duration of analgesia of supraclavicular brachial plexus block. J. Anest. Inten. Care Med. 2019, 9, 555756.

132. Kanazi, G.E.; Aouad, M.T.; Jabbour-Khoury, S.I.; Al Jazzar, M.D.; Alameddine, M.M.; Al-Yaman, R.; Bulbul, M.; Baraka, A.S. Effect of low-dose dexmedetomidine or clonidine on the characteristics of bupivacaine spinal block. Acta Anaesthesiol. Scand. 2006, 50, 222-227. [CrossRef] [PubMed]

133. Madan, R.; Bharti, N.; Shende, D.; Khokhar, S.K.; Kaul, H.L. A dose response study of clonidine with local anesthetic mixture for peribulbar block: A comparison of three doses. Anesth. Analg. 2001, 93, 1593-1597. [CrossRef] [PubMed]

134. Memiş, D.; Turan, A.; Karamanlioĝlu, B.; Pamukçu, Z.; Kurt, I. Adding dexmedetomidine to lidocaine for intravenous regional anesthesia. Anesth. Analg. 2004, 98, 835-840. [CrossRef]

135. Singelyn, F.J.; Gouverneur, J.-M.; Robert, A. A minimum dose of clonidine added to mepivacaine prolongs the duration of anesthesia and analgesia after axillary brachial plexus block. Anesth. Analg. 1996, 83, 1046-1050. [CrossRef]

136. Tschernko, E.M.; Klepetko, H.; Gruber, E.; Kritzinger, M.; Klimscha, W.; Jandrasits, O.; Haider, W. Clonidine added to the anesthetic solution enhances analgesia and improves oxygenation after intercostal nerve block for thoracotomy. Anesth. Analg. 1998, 87, 107-111.

137. Eisenach, J.C.; De Kock, M.; Klimscha, W. $\alpha_{2}$-Adrenergic agonists for regional anesthesia. A clinical review of clonidine (1984-1995). Anesthesiology 1996, 85, 655-674. [CrossRef]

138. Concepcion, M.; Maddi, R.; Francis, D.; Rocco, A.G.; Murray, E.; Covino, B.G. Vasoconstrictors in spinal anesthesia with tetracaine - a comparison of epinephrine and phenylephrine. Anesth. Analg. 1984, 63, 134-138. [CrossRef] [PubMed]

139. Vaida, G.T.; Moss, P.; Capan, L.M.; Turndorf, H. Prolongation of lidocaine spinal anesthesia with phenylephrine. Anesth. Analg. 1986, 65, 781-785. [CrossRef] [PubMed]

140. Gaumann, D.M.; Brunet, P.C.; Jirounek, P. Clonidine enhances the effects of lidocaine on C-fiber action potential. Anesth. Analg. 1992, 74, 719-725. [CrossRef] [PubMed]

141. Kawasaki, Y.; Kumamoto, E.; Furue, H.; Yoshimura, M. $\alpha_{2}$ Adrenoceptor-mediated presynaptic inhibition of primary afferent glutamatergic transmission in rat substantia gelatinosa neurons. Anesthesiology 2003, 98, 682-689. [CrossRef]

142. Pan, Y.-Z.; Li, D.-P.; Pan, H.-L. Inhibition of glutamatergic synaptic input to spinal lamina $\mathrm{II}_{\mathrm{O}}$ neurons by presynaptic $\alpha_{2}$-adrenergic receptors. J. Neurophysiol. 2002, 87, 1938-1947. [CrossRef] [PubMed]

143. Butterworth, J.F. IV.; Strichartz, G.R. The $\alpha_{2}$-adrenergic agonists clonidine and guanfacine produce tonic and phasic block of conduction in rat sciatic nerve fibers. Anesth. Analg. 1993, 76, 295-301.

144. Starke, K.; Wagner, J.; Schümann, H.J. Adrenergic neuron blockade by clonidine: Comparison with guanethidine and local anesthetics. Arch. Int. Pharmacodyn. 1972, 195, 291-308. [PubMed]

145. Ishii, H.; Kohno, T.; Yamakura, T.; Ikoma, M.; Baba, H. Action of dexmedetomidine on the substantia gelatinosa neurons of the rat spinal cord. Eur. J. Neurosci. 2008, 27, 3182-3190. [CrossRef]

146. Yoshitomi, T.; Kohjitani, A.; Maeda, S.; Higuchi, H.; Shimada, M.; Miyawaki, T. Dexmedetomidine enhances the local anesthetic action of lidocaine via an $\alpha$-2A adrenoceptor. Anesth. Analg. 2008, 107, 96-101. [CrossRef]

147. Mohamed, S.A.; Sayed, D.M.; El Sherif, F.A.; Abd El-Rahman, A.M. Effect of local wound infiltration with ketamine versus dexmedetomidine on postoperative pain and stress after abdominal hysterectomy, a randomized trial. Eur. J. Pain 2018, 22, 951-960. [CrossRef]

148. Oda, A.; Iida, H.; Tanahashi, S.; Osawa, Y.; Yamaguchi, S.; Dohi, S. Effects of $\alpha_{2}$-adrenoceptor agonists on tetrodotoxin-resistant $\mathrm{Na}^{+}$channels in rat dorsal root ganglion neurons. Eur. J. Anaesthesiol. 2007, 24, 934-941. [CrossRef] [PubMed]

149. Coughlan, M.G.; Lee, J.G.; Bosnjak, Z.J.; Schmeling, W.T.; Kampine, J.P.; Warltier, D.C. Direct coronary and cerebral vascular responses to dexmedetomidine. Significance of endogenous nitric oxide synthesis. Anesthesiology 1992, 77, 998-1006. [CrossRef] [PubMed]

150. Correa-Sales, C.; Rabin, B.C.; Maze, M. A hypnotic response to dexmedetomidine, an $\alpha_{2}$ agonist, is mediated in the locus coeruleus in rats. Anesthesiology 1992, 76, 948-952. [CrossRef] [PubMed]

151. Sjöholm, B.; Voutilainen, R.; Luomala, K.; Savola, J.-M.; Scheinin, M. Characterization of $\left[{ }^{3} H\right]$ atipamezole as a radioligand for $\alpha_{2}$-adrenoceptors. Eur. J. Pharmacol. 1992, 215, 109-117. [CrossRef] 
152. MacDonald, E.; Kobilka, B.K.; Scheinin, M. Gene targeting-homing in on $\alpha_{2}$-adrenoceptor-subtype function. Trends Pharmacol. Sci. 1997, 18, 211-219. [CrossRef]

153. Virtanen, R. Pharmacological profiles of medetomidine and its antagonist, atipamezole. Acta Vet. Scand. 1989, 85, 29-37.

154. Bylund, D.B.; Eikenberg, D.C.; Hieble, J.P.; Langer, S.Z.; Lefkowitz, R.J.; Minneman, K.P.; Molinoff, P.B.; Ruffolo, R.R.; Trendelenburg, U. International union of pharmacology nomenclature of adrenoceptors. Pharmacol. Rev. 1994, 46, 121-136.

155. Stoetzer, C.; Martell, C.; de la Roche, J.; Leffler, A. Inhibition of voltage-gated $\mathrm{Na}^{+}$channels by bupivacaine is enhanced by the adjuvants buprenorphine, ketamine, and clonidine. Reg. Anesth. Pain Med. 2017, 42, 462-468. [CrossRef]

156. Chen, B.-S.; Peng, H.; Wu, S.-N. Dexmedetomidine, an $\alpha_{2}$-adrenergic agonist, inhibits neuronal delayed-rectifier potassium current and sodium current. Br. J. Anaesth. 2009, 103, 244-254. [CrossRef]

157. Ebert, T.J.; Hall, J.E.; Barney, J.A.; Uhrich, T.D.; Colinco, M.D. The effects of increasing plasma concentrations of dexmedetomidine in humans. Anesthesiology 2000, 93, 382-394. [CrossRef]

158. Slingsby, L.S.; Taylor, P.M. Thermal antinociception after dexmedetomidine administration in cats: A dose-finding study. J. Vet. Pharmacol. Ther. 2008, 31, 135-142. [CrossRef] [PubMed]

159. Bharti, N.; Sardana, D.K.; Bala, I. The analgesic efficacy of dexmedetomidine as an adjunct to local anesthetics in supraclavicular brachial plexus block: A randomized controlled trial. Anesth. Analg. 2015, 121, 1655-1660. [CrossRef] [PubMed]

160. Macdonald, R.L. Cellular effects of antiepileptic drugs. In Epilepsy: A Comprehensive Textbook; Engel, J., Jr., Pedley, T.A., Eds.; Lippincon-Raven Publishers: Philadelphia, PA, USA, 1997; pp. 1383-1391.

161. Xie, X.; Dale, T.J.; John, V.H.; Cater, H.L.; Peakman, T.C.; Clare, J.J. Electrophysiological and pharmacological properties of the human brain type IIA $\mathrm{Na}^{+}$channel expressed in a stable mammalian cell line. Pflügers Arch. 2001, 441, 425-433. [CrossRef] [PubMed]

162. McLean, M.J.; Macdonald, R.L. Carbamazepine and 10,11-epoxycarbamazepine produce use- and voltage-dependent limitation of rapidly firing action potentials of mouse central neurons in cell culture. J. Pharmacol. Exp. Ther. 1986, 238, 727-738.

163. Cruccu, G.; Gronseth, G.; Alksne, J.; Argoff, C.; Brainin, M.; Burchiel, K.; Nurmikko, T.; Zakrzewska, J.M. AAN-EFNS guidelines on trigeminal neuralgia management. Eur. J. Neurol. 2008, 15, 1013-1028. [CrossRef]

164. Vargas-Espinosa, M.-L.; Sanmartí-García, G.; Vázquez-Delgado, E.; Gay-Escoda, C. Antiepileptic drugs for the treatment of neuropathic pain: A systematic review. Med. Oral Patol. Oral Cir. Bucal 2012, 17, e786-e793. [CrossRef]

165. Benes, J.; Parada, A.; Figueiredo, A.A.; Alves, P.C.; Freitas, A.P.; Learmonth, D.A.; Cunha, R.A.; Garrett, J.; Soares-da-Silva, P. Anticonvulsant and sodium channel-blocking properties of novel 10,11-dihydro-5H-dibenz $[b, f]$ azepine-5- carboxamide derivatives. J. Med. Chem. 1999, 42, 2582-2587. [CrossRef]

166. Huang, C.-W.; Huang, C.-C.; Lin, M.-W.; Tsai, J.-J.; Wu, S.-N. The synergistic inhibitory actions of oxcarbazepine on voltage-gated sodium and potassium currents in differentiated NG108-15 neuronal cells and model neurons. Int. J. Neuropsychopharmacol. 2008, 11, 597-610. [CrossRef]

167. Kuo, C.-C. A common anticonvulsant binding site for phenytoin, carbamazepine, and lamotrigine in neuronal $\mathrm{Na}^{+}$channels. Mol. Pharmacol. 1998, 54, 712-721.

168. Lang, D.G.; Wang, C.M.; Cooper, B.R. Lamotrigine, phenytoin and carbamazepine interactions on the sodium current present in N4TG1 mouse neuroblastoma cells. J. Pharmacol. Exp. Ther. 1993, 266, 829-835.

169. Molnár, P.; Erdö, S.L. Vinpocetine is as potent as phenytoin to block voltage-gated $\mathrm{Na}^{+}$channels in rat cortical neurons. Eur. J. Pharmacol. 1995, 273, 303-306. [CrossRef]

170. Qiao, X.; Sun, G.; Clare, J.J.; Werkman, T.R.; Wadman, W.J. Properties of human brain sodium channel $\alpha$-subunits expressed in HEK293 cells and their modulation by carbamazepine, phenytoin and lamotrigine. Br. J. Pharmacol. 2014, 171, 1054-1067. [CrossRef] [PubMed]

171. Neumcke, B.; Schwarz, J.R.; Stämpfli, R. A comparison of sodium currents in rat and frog myelinated nerve: Normal and modified sodium inactivation. J. Physiol. 1987, 382, 175-191. [CrossRef] [PubMed]

172. Maneuf, Y.P.; Gonzalez, M.I.; Sutton, K.S.; Chung, F.-Z.; Pinnock, R.D.; Lee, K. Cellular and molecular action of the putative GABA-mimetic, gabapentin. Cell. Mol. Life Sci. 2003, 60, 742-750. [PubMed] 
173. Zona, C.; Ciotti, M.T.; Avoli, M. Topiramate attenuates voltage-gated sodium currents in rat cerebellar granule cells. Neurosci. Lett. 1997, 231, 123-126. [CrossRef]

174. Curia, G.; Aracri, P.; Colombo, E.; Scalmani, P.; Mantegazza, M.; Avanzini, G.; Franceschetti, S. Phosphorylation of sodium channels mediated by protein kinase-C modulates inhibition by topiramate of tetrodotoxin-sensitive transient sodium current. Br. J. Pharmacol. 2007, 150, 792-797. [CrossRef]

175. Chapman, A.; Keane, P.E.; Meldrum, B.S.; Simiand, J.; Vernieres, J.C. Mechanism of anticonvulsant action of valproate. Prog. Neurobiol. 1982, 19, 315-359. [CrossRef]

176. Perucca, E. A pharmacological and clinical review on topiramate, a new antiepileptic drug. Pharmacol. Res. 1997, 35, 241-256. [CrossRef]

177. Braga, M.F.M.; Aroniadou-Anderjaska, V.; Li, H.; Rogawski, M.A. Topiramate reduces excitability in the basolateral amygdala by selectively inhibiting GluK1 (GluR5) kainate receptors on interneurons and positively modulating $\mathrm{GABA}_{\mathrm{A}}$ receptors on principal neurons. J. Pharmacol. Exp. Ther. 2009, 330, 558-566. [CrossRef]

178. Lee, C.-Y.; Fu, W.-M.; Chen, C.-C.; Su, M.-J.; Liou, H.-H. Lamotrigine inhibits postsynaptic AMPA receptor and glutamate release in the dentate gyrus. Epilepsia 2008, 49, 888-897. [CrossRef]

179. Blackburn-Munro, G.; Ibsen, N.; Erichsen, H.K. A comparison of the anti-nociceptive effects of voltage-activated $\mathrm{Na}^{+}$channel blockers in the formalin test. Eur. J. Pharmacol. 2002, 445, 231-238. [CrossRef]

180. Shannon, H.E.; Eberle, E.L.; Peters, S.C. Comparison of the effects of anticonvulsant drugs with diverse mechanisms of action in the formalin test in rats. Neuropharmacology 2005, 48, 1012-1020. [CrossRef]

181. Douglas-Hall, P.; Dzahini, O.; Gaughran, F.; Bile, A.; Taylor, D. Variation in dose and plasma level of lamotrigine in patients discharged from a mental health trust. Ther. Adv. Psychopharmacol. 2017, 7, 17-24. [CrossRef] [PubMed]

182. Morselli, P.L. Carbamazepine: Absorption, distribution, and excretion. In Antiepileptic Drugs, 4th ed.; Levy, R.H., Mattson, R.H., Meldrum, B.S., Eds.; Raven Press: New York, NY, USA, 1995; pp. 515-528.

183. Ardid, D.; Jourdan, D.; Mestre, C.; Villanueva, L.; Le Bars, D.; Eschalier, A. Involvement of bulbospinal pathways in the antinociceptive effect of clomipramine in the rat. Brain Res. 1995, 695, 253-256. [CrossRef]

184. Max, M.B.; Lynch, S.A.; Muir, J.; Shoaf, S.E.; Smoller, B.; Dubner, R. Effects of desipramine, amitriptyline, and fluoxetine on pain in diabetic neuropathy. N. Engl. J. Med. 1992, 326, 1250-1256. [CrossRef] [PubMed]

185. Anjaneyulu, M.; Chopra, K. Possible involvement of cholinergic and opioid receptor mechanisms in fluoxetine mediated antinociception response in streptozotocin-induced diabetic mice. Eur. J. Pharmacol. 2006, 538, 80-84. [CrossRef] [PubMed]

186. Cervantes-Durán, C.; Rocha-González, H.I.; Granados-Soto, V. Peripheral and spinal 5-HT receptors participate in the pronociceptive and antinociceptive effects of fluoxetine in rats. Neuroscience 2013, 252, 396-409. [CrossRef]

187. Ghelardini, C.; Galeotti, N.; Bartolini, A. Antinociception induced by amitriptyline and imipramine is mediated by $\alpha_{2 \mathrm{~A}}$-adrenoceptors. Jpn. J. Pharmacol. 2000, 82, 130-137. [CrossRef]

188. Hall, H.; Ögren, S.-O. Effects of antidepressant drugs on different receptors in the brain. Eur. J. Pharmacol. 1981, 70, 393-407. [CrossRef]

189. O'Donnell, J.M.; Shelton, R.C. Drug therapy of depression and anxiety disorders. In Goodman E Gilman's the Pharmacological Basis of Therapeutics, 12th ed.; Brunton, L.L., Chabner, B.A., Knollmann, B.C., Eds.; McGraw-Hill, Medical Publishing Division: New York, NY, USA, 2011; pp. 397-415.

190. Wong, D.T.; Bymaster, F.P. Dual serotonin and noradrenaline uptake inhibitor class of antidepressants-Potential for greater efficacy or just hype? Prog. Drug Res. 2002, 58, 169-222.

191. Traboulsie, A.; Chemin, J.; Kupfer, E.; Nargeot, J.; Lory, P. T-type calcium channels are inhibited by fluoxetine and its metabolite norfluoxetine. Mol. Pharmacol. 2006, 69, 1963-1968. [CrossRef] [PubMed]

192. Wu, W.; Ye, Q.; Wang, W.; Yan, L.; Wang, Q.; Xiao, H.; Wan, Q. Amitriptyline modulates calcium currents and intracellular calcium concentration in mouse trigeminal ganglion neurons. Neurosci. Lett. 2012, 506, 307-311. [CrossRef] [PubMed]

193. Reynolds, I.J.; Miller, R.J. Tricyclic antidepressants block N-methyl-D-aspartate receptors: Similarities to the action of zinc. Br. J. Pharmacol. 1988, 95, 95-102. [CrossRef] [PubMed]

194. Sernagor, E.; Kuhn, D.; Vyklicky, L., Jr.; Mayer, M.L. Open channel block of NMDA receptor responses evoked by tricyclic antidepressants. Neuron 1989, 2, 1221-1227. [CrossRef] 
195. Watanabe, Y.; Saito, H.; Abe, K. Tricyclic antidepressants block NMDA receptor-mediated synaptic responses and induction of long-term potentiation in rat hippocampal slices. Neuropharmacology 1993, 32, 479-486. [CrossRef]

196. Nagata, K.; Imai, T.; Yamashita, T.; Tsuda, M.; Tozaki-Saitoh, H.; Inoue, K. Antidepressants inhibit $\mathrm{P} 2 \mathrm{X}_{4}$ receptor function: A possible involvement in neuropathic pain relief. Mol. Pain 2009, 5, 20. [CrossRef]

197. Le Cudennec, C.; Castagné, V. Face-to-face comparison of the predictive validity of two models of neuropathic pain in the rat: Analgesic activity of pregabalin, tramadol and duloxetine. Eur. J. Pharmacol. 2014, 735, 17-25. [CrossRef]

198. Russell, I.J.; Mease, P.J.; Smith, T.R.; Kajdasz, D.K.; Wohlreich, M.M.; Detke, M.J.; Walker, D.J.; Chappell, A.S.; Arnold, L.M. Efficacy and safety of duloxetine for treatment of fibromyalgia in patients with or without major depressive disorder: Results from a 6-month, randomized, double-blind, placebo-controlled, fixed-dose trial. Pain 2008, 136, 432-444. [CrossRef]

199. Wong, D.T.; Bymaster, F.P.; Mayle, D.A.; Reid, L.R.; Krushinski, J.H.; Robertson, D.W. LY248686, a new inhibitor of serotonin and norepinephrine uptake. Neuropsychopharmacology 1993, 8, 23-33. [CrossRef]

200. Müller, N.; Schennach, R.; Riedel, M.; Möller, H.-J. Duloxetine in the treatment of major psychiatric and neuropathic disorders. Expert Rev. Neurother. 2008, 8, 527-536. [CrossRef]

201. Stark, P.; Fuller, R.W.; Wong, D.T. The pharmacologic profile of fluoxetine. J. Clin. Psychiatry 1985, 46, 7-13. [PubMed]

202. Korzeniewska-Rybicka, I.; Płaźnik, A. Analgesic effect of antidepressant drugs. Pharmacol. Biochem. Behav. 1998, 59, 331-338. [CrossRef]

203. Richeimer, S.H.; Bajwa, Z.H.; Kahraman, S.S.; Ransil, B.J.; Warfield, C.A. Utilization patterns of tricyclic antidepressants in a multidisciplinary pain clinic: A survey. Clin. J. Pain 1997, 13, 324-329. [CrossRef] [PubMed]

204. Gerner, P.; Mujtaba, M.; Sinnott, C.J.; Wang, G.K. Amitriptyline versus bupivacaine in rat sciatic nerve blockade. Anesthesiology 2001, 94, 661-667. [CrossRef] [PubMed]

205. Davidoff, G.; Guarracini, M.; Roth, E.; Sliwa, J.; Yarkony, G. Trazodone hydrochloride in the treatment of dysesthetic pain in traumatic myelopathy: A randomized, double-blind, placebo-controlled study. Pain 1987, 29, 151-161. [CrossRef]

206. Okuda, K.; Takanishi, T.; Yoshimoto, K.; Ueda, S. Trazodone hydrochloride attenuates thermal hyperalgesia in a chronic constriction injury rat model. Eur. J. Anaesthesiol. 2003, 20, 409-415. [CrossRef]

207. Richelson, E.; Pfenning, M. Blockade by antidepressants and related compounds of biogenic amine uptake into rat brain synaptosomes: Most antidepressants selectively block norepinephrine uptake. Eur. J. Pharmacol. 1984, 104, 277-286. [CrossRef]

208. Schreiber, S.; Backer, M.M.; Herman, I.; Shamir, D.; Boniel, T.; Pick, C.G. The antinociceptive effect of trazodone in mice is mediated through both $\mu$-opioid and serotonergic mechanisms. Behav. Brain Res. 2000, 114, 51-56. [CrossRef]

209. Baastrup, C.; Finnerup, N.B. Pharmacological management of neuropathic pain following spinal cord injury. CNS Drugs 2008, 22, 455-475. [CrossRef]

210. Stoetzer, C.; Papenberg, B.; Doll, T.; Völker, M.; Heineke, J.; Stoetzer, M.; Wegner, F.; Leffler, A. Differential inhibition of cardiac and neuronal $\mathrm{Na}^{+}$channels by the selective serotonin-norepinephrine reuptake inhibitors duloxetine and venlafaxine. Eur. J. Pharmacol. 2016, 783, 1-10. [CrossRef]

211. Wang, S.-Y.; Calderon, J.; Wang, G.K. Block of neuronal $\mathrm{Na}^{+}$channels by antidepressant duloxetine in a state-dependent manner. Anesthesiology 2010, 113, 655-665. [CrossRef] [PubMed]

212. Pancrazio, J.J.; Kamatchi, G.L.; Roscoe, A.K.; Lynch, C., 3rd. Inhibition of neuronal $\mathrm{Na}^{+}$channels by antidepressant drugs. J. Pharmacol. Exp. Ther. 1998, 284, 208-214. [PubMed]

213. Ishii, Y.; Sumi, T. Amitriptyline inhibits striatal efflux of neurotransmitters via blockade of voltage-dependent $\mathrm{Na}^{+}$channels. Eur. J. Pharmacol. 1992, 221, 377-380. [CrossRef]

214. Leffler, A.; Reiprich, A.; Mohapatra, D.P.; Nau, C. Use-dependent block by lidocaine but not amitriptyline is more pronounced in tetrodotoxin (TTX)-resistant Nav1.8 than in TTX-sensitive $\mathrm{Na}^{+}$channels. J. Pharmacol. Exp. Ther. 2007, 320, 354-364. [CrossRef] [PubMed]

215. Nicholson, G.M.; Blanche, T.; Mansfield, K.; Tran, Y. Differential blockade of neuronal voltage-gated $\mathrm{Na}^{+}$and $\mathrm{K}^{+}$channels by antidepressant drugs. Eur. J. Pharmacol. 2002, 452, 35-48. [CrossRef] 
216. Song, J.-H.; Ham, S.-S.; Shin, Y.-K.; Lee, C.-S. Amitriptyline modulation of $\mathrm{Na}^{+}$channels in rat dorsal root ganglion neurons. Eur. J. Pharmacol. 2000, 401, 297-305. [CrossRef]

217. Wang, G.K.; Russell, C.; Wang, S.-Y. State-dependent block of voltage-gated $\mathrm{Na}^{+}$channels by amitriptyline via the local anesthetic receptor and its implication for neuropathic pain. Pain 2004, 110, 166-174. [CrossRef]

218. Yan, L.; Wang, Q.; Fu, Q.; Ye, Q.; Xiao, H.; Wan, Q. Amitriptyline inhibits currents and decreases the mRNA expression of voltage-gated sodium channels in cultured rat cortical neurons. Brain Res. 2010, 1336, 1-9. [CrossRef]

219. Dick, I.E.; Brochu, R.M.; Purohit, Y.; Kaczorowski, G.J.; Martin, W.J.; Priest, B.T. Sodium channel blockade may contribute to the analgesic efficacy of antidepressants. J. Pain 2007, 8, 315-324. [CrossRef]

220. Liang, J.; Liu, X.; Pan, M.; Dai, W.; Dong, Z.; Wang, X.; Liu, R.; Zheng, J.; Yu, S. Blockade of Nav1.8 currents in nociceptive trigeminal neurons contributes to anti-trigeminovascular nociceptive effect of amitriptyline. Neuromolecular Med. 2014, 16, 308-321. [CrossRef]

221. Catterall, W.A.; Mackie, K. Local anesthetics. In Goodman E Gilman's the Pharmacological Basis of Therapeutics, 12th ed.; Brunton, L.L., Chabner, B.A., Knollmann, B.C., Eds.; McGraw-Hill, Medical Publishing Division: New York, NY, USA, 2011; pp. 565-582.

222. Caruso, R.; Ostuzzi, G.; Turrini, G.; Ballette, F.; Recla, E.; Dall'Olio, R.; Croce, E.; Casoni, B.; Grassi, L.; Barbui, C. Beyond pain: Can antidepressants improve depressive symptoms and quality of life in patients with neuropathic pain? A systematic review and meta-analysis. Pain 2019, 160, 2186-2198. [CrossRef] [PubMed]

223. Mika, J.; Zychowska, M.; Makuch, W.; Rojewska, E.; Przewlocka, B. Neuronal and immunological basis of action of antidepressants in chronic pain-Clinical and experimental studies. Pharmacol. Rep. 2013, 65, 1611-1621. [CrossRef]

224. Banafshe, H.R.; Hajhashemi, V.; Minaiyan, M.; Mesdaghinia, A.; Abed, A. Antinociceptive effects of maprotiline in a rat model of peripheral neuropathic pain: Possible involvement of opioid system. Iran J. Basic Med. Sci. 2015, 18, 752-757. [CrossRef]

225. Kirillova, I.; Teliban, A.; Gorodetskaya, N.; Grossmann, L.; Bartsch, F.; Rausch, V.H.; Struck, M.; Tode, J.; Baron, R.; Jänig, W. Effect of local and intravenous lidocaine on ongoing activity in injured afferent nerve fibers. Pain 2011, 152, 1562-1571. [CrossRef]

226. Shin, J.W.; Pancaro, C.; Wang, C.F.; Gerner, P. Low-dose systemic bupivacaine prevents the development of allodynia after thoracotomy in rats. Anesth. Analg. 2008, 107, 1587-1591. [CrossRef]

227. Delorme, C.; Navez, M.L.; Legout, V.; Deleens, R.; Moyse, D. Treatment of neuropathic pain with 5\% lidocaine-medicated plaster: Five years of clinical experience. Pain Res. Manag. 2011, 16, 259-263. [CrossRef]

228. Kalso, E.; Tramèr, M.R.; McQuay, H.J.; Moore, R.A. Systemic local-anaesthetic-type drugs in chronic pain: A systematic review. Eur. J. Pain 1998, 2, 3-14. [CrossRef]

229. Tremont-Lukats, I.W.; Challapalli, V.; McNicol, E.D.; Lau, J.; Carr, D.B. Systemic administration of local anesthetics to relieve neuropathic pain: A systematic review and meta-analysis. Anesth. Analg. 2005, 101, 1738-1749. [CrossRef]

230. Zhu, B.; Zhou, X.; Zhou, Q.; Wang, H.; Wang, S.; Luo, K. Intra-venous lidocaine to relieve neuropathic pain: A systematic review and meta-analysis. Front. Neurol. 2019, 10, 954. [CrossRef]

231. Hermanns, H.; Hollmann, M.W.; Stevens, M.F.; Lirk, P.; Brandenburger, T.; Piegeler, T.; Werdehausen, R. Molecular mechanisms of action of systemic lidocaine in acute and chronic pain: A narrative review. Br. J. Anaesth. 2019, 123, 335-349. [CrossRef]

232. Hille, B. Ionic Channels of Excitable Membranes; Sinauer Associates Inc.: Sunderland, MA, USA, 1984.

233. Chan, V.W.S.; Weisbrod, M.J.; Kaszas, Z.; Dragomir, C. Comparison of ropivacaine and lidocaine for intravenous regional anesthesia in volunteers: A preliminary study on anesthetic efficacy and blood level. Anesthesiology 1999, 90, 1602-1608. [CrossRef]

234. McClellan, K.J.; Faulds, D. Ropivacaine: An update of its use in regional anaesthesia. Drugs 2000, 60, 1065-1093. [CrossRef] [PubMed]

235. Bader, A.M.; Datta, S.; Flanagan, H.; Covino, B.G. Comparison of bupivacaine- and ropivacaine-induced conduction blockade in the isolated rabbit vagus nerve. Anesth. Analg. 1989, 68, 724-727. [CrossRef] [PubMed] 
236. Yilmaz-Rastoder, E.; Gold, M.S.; Hough, K.A.; Gebhart, G.F.; Williams, B.A. Effect of adjuvant drugs on the action of local anesthetics in isolated rat sciatic nerves. Reg. Anesth. Pain Med. 2012, 37, 403-409. [CrossRef] [PubMed]

237. Lee-Son, S.; Wang, G.K.; Concus, A.; Crill, E.; Strichartz, G. Stereoselective inhibition of neuronal sodium channels by local anesthetics. Evidence for two sites of action? Anesthesiology 1992, 77, 324-335. [CrossRef] [PubMed]

238. Foster, R.H.; Markham, A. Levobupivacaine: A review of its pharmacology and use as a local anaesthetic. Drugs 2000, 59, 551-579. [CrossRef]

239. Vladimirov, M.; Nau, C.; Mok, W.M.; Strichartz, G. Potency of bupivacaine stereoisomers tested in vitro and in vivo: Biochemical, electrophysiological, and neurobehavioral studies. Anesthesiology 2000, 93, 744-755. [CrossRef]

240. Bedford, J.A.; Turner, C.E.; Elsohly, H.N. Local anesthetic effects of cocaine and several extracts of the coca leaf (E. coca). Pharmacol. Biochem. Behav. 1984, 20, 819-821. [CrossRef]

241. Pagala, M.K.D.; Venkatachari, S.A.T.; Herzlich, B.; Ravindran, K.; Namba, T.; Grob, D. Effect of cocaine on responses of mouse phrenic nerve-diaphragm preparation. Life Sci. 1991, 48, 795-802. [CrossRef]

242. Carney, T.P. Alkaloids as local anesthetics. In The Alkaloids; Manske, R.H.F., Ed.; Academic Press: New York, NY, USA, 1955; Volume 5, pp. 211-227.

243. Matthews, J.C.; Collins, A. Interactions of cocaine and cocaine congeners with sodium channels. Biochem. Pharmacol. 1983, 32, 455-460. [CrossRef]

244. O'Leary, M.E.; Chahine, M. Cocaine binds to a common site on open and inactivated human heart (Nav1.5) sodium channels. J. Physiol. 2002, 541, 701-716. [CrossRef] [PubMed]

245. Liu, D.; Hariman, R.J.; Bauman, J.L. Cocaine concentration-effect relationship in the presence and absence of lidocaine: Evidence of competitive binding between cocaine and lidocaine. J. Pharmacol. Exp. Ther. 1996, 276, 568-577. [PubMed]

246. Chen, Y.-H.; Lin, C.-H.; Lin, P.-L.; Tsai, M.-C. Cocaine elicits action potential bursts in a central snail neuron: The role of delayed rectifying $\mathrm{K}^{+}$current. Neuroscience 2006, 138, 257-280. [CrossRef] [PubMed]

247. Štolc, S.; Mai, P.-M. Comparison of local anesthetic activity of pentacaine (trapencaine) and some of its derivatives by three different techniques. Pharmazie 1993, 48, 210-212. [PubMed]

248. Butterworth, J.F. IV.; Lief, P.A.; Strichartz, G.R. The pH-dependent local anesthetic activity of diethylaminoethanol, a procaine metabolite. Anesthesiology 1988, 68, 501-506. [CrossRef]

249. Ribeiro, J.A.; Sebastião, A.M. Antagonism of tetrodotoxin- and procaine-induced axonal blockade by adenine nucleotides in the frog sciatic nerve. Br. J. Pharmacol. 1984, 81, 277-282. [CrossRef]

250. Kalichman, M.W.; Moorhouse, D.F.; Powell, H.C.; Myers, R.R. Relative neural toxicity of local anesthetics. J. Neuropathol. Exp. Neurol. 1993, 52, 234-240. [CrossRef]

251. Lee, H.-S. Recent advances in topical anesthesia. J. Dent. Anesth. Pain Med. 2016, 16, 237-244. [CrossRef]

252. Thygesen, M.M.; Rasmussen, M.M.; Madsen, J.G.; Pedersen, M.; Lauridsen, H. Propofol (2, 6-diisopropylphenol) is an applicable immersion anesthetic in the axolotl with potential uses in hemodynamic and neurophysiological experiments. Regeneration 2017, 4, 124-131. [CrossRef]

253. Guénette, S.A.; Giroux, M.-C.; Vachon, P. Pain perception and anaesthesia in research frogs. Exp. Anim. 2013, 62, 87-92.

254. Vanable, J.W. Benzocaine: An excellent amphibian anesthetic. Axolotol. Newsl. 1985, 14, 19-21.

255. Gissen, A.J.; Covino, B.G.; Gregus, J. Differential sensitivities of mammalian nerve fibers to local anesthetic agents. Anesthesiology 1980, 53, 467-474. [CrossRef] [PubMed]

256. Nassar, M.A.; Stirling, L.C.; Forlani, G.; Baker, M.D.; Matthews, E.A.; Dickenson, A.H.; Wood, J.N. Nociceptor-specific gene deletion reveals a major role for $\mathrm{Na}_{\mathrm{v}} 1.7$ (PN1) in acute and inflammatory pain. Proc. Natl. Acad. Sci. USA 2004, 101, 12706-12711. [CrossRef] [PubMed]

257. Guimarães, A.G.; Quintans, J.S.S.; Quintans-Júnior, L.J. Monoterpenes with analgesic activity-A systematic review. Phytother. Res. 2013, 27,1-15. [CrossRef]

258. Tsuchiya, H. Anesthetic agents of plant origin: A review of phytochemicals with anesthetic activity. Molecules 2017, 22, 1369. [CrossRef]

259. Kawasaki, H.; Mizuta, K.; Fujita, T.; Kumamoto, E. Inhibition by menthol and its related chemicals of compound action potentials in frog sciatic nerves. Life Sci. 2013, 92, 359-367. [CrossRef] 
260. Matsushita, A.; Ohtsubo, S.; Fujita, T.; Kumamoto, E. Inhibition by TRPA1 agonists of compound action potentials in the frog sciatic nerve. Biochem. Biophys. Res. Commun. 2013, 434, 179-184. [CrossRef]

261. Ohtsubo, S.; Fujita, T.; Matsushita, A.; Kumamoto, E. Inhibition of the compound action potentials of frog sciatic nerves by aroma oil compounds having various chemical structures. Pharmacol. Res. Perspect. 2015, 3, e00127. [CrossRef]

262. Kumamoto, E. Effects of plant-derived compounds on excitatory synaptic transmission and nerve conduction in the nervous system - involvement in pain modulation. Curr. Top. Phytochem. 2018, 14, 45-70.

263. Cho, J.S.; Kim, T.H.; Lim, J.-M.; Song, J.-H. Effects of eugenol on $\mathrm{Na}^{+}$currents in rat dorsal root ganglion neurons. Brain Res. 2008, 1243, 53-62. [CrossRef]

264. Haeseler, G.; Maue, D.; Grosskreutz, J.; Bufler, J.; Nentwig, B.; Piepenbrock, S.; Dengler, R.; Leuwer, M. Voltage-dependent block of neuronal and skeletal muscle sodium channels by thymol and menthol. Eur. J. Anaesthesiol. 2002, 19, 571-579. [CrossRef] [PubMed]

265. Joca, H.C.; Cruz-Mendes, Y.; Oliveira-Abreu, K.; Maia-Joca, R.P.M.; Barbosa, R.; Lemos, T.L.; Lacerda Beirão, P.S.; Leal-Cardoso, J.H. Carvacrol decreases neuronal excitability by inhibition of voltage-gated sodium channels. J. Nat. Prod. 2012, 75, 1511-1517. [CrossRef] [PubMed]

266. Leal-Cardoso, J.H.; da Silva-Alves, K.S.; Ferreira-da-Silva, F.W.; dos Santos-Nascimento, T.; Joca, H.C.; de Macedo, F.H.P.; de Albuquerque-Neto, P.M.; Magalhães, P.J.C.; Lahlou, S.; Cruz, J.S.; et al. Linalool blocks excitability in peripheral nerves and voltage-dependent $\mathrm{Na}^{+}$current in dissociated dorsal root ganglia neurons. Eur. J. Pharmacol. 2010, 645, 86-93. [CrossRef] [PubMed]

267. De Araújo, D.A.M.; Freitas, C.; Cruz, J.S. Essential oils components as a new path to understand ion channel molecular pharmacology. Life Sci. 2011, 89, 540-544. [CrossRef] [PubMed]

268. Nozoe, T. Über die farbstoffe im holzteile des "hinoki" baumes. I. Hinokitin und hinokitiol. Bull. Chem. Soc. Jpn. 1936, 11, 295-298. [CrossRef]

269. Magori, N.; Fujita, T.; Kumamoto, E. Hinokitiol inhibits compound action potentials in the frog sciatic nerve. Eur. J. Pharmacol. 2018, 819, 254-260. [CrossRef]

270. Baba, T.; Nakano, H.; Tamai, K.; Sawamura, D.; Hanada, K.; Hashimoto, I.; Arima, Y. Inhibitory effect of $\beta$-thujaplicin on ultraviolet B-induced apoptosis in mouse keratinocytes. J. Investig. Dermatol. 1998, 110, 24-28. [CrossRef]

271. Shih, Y.-H.; Lin, D.-J.; Chang, K.-W.; Hsia, S.-M.; Ko, S.-Y.; Lee, S.-Y.; Hsue, S.-S.; Wang, T.-H.; Chen, Y.-L.; Shieh, T.-M. Evaluation physical characteristics and comparison antimicrobial and anti-inflammation potentials of dental root canal sealers containing hinokitiol in vitro. PLoS ONE 2014, 9, e94941. [CrossRef]

272. Morita, Y.; Matsumura, E.; Okabe, T.; Shibata, M.; Sugiura, M.; Ohe, T.; Tsujibo, H.; Ishida, N.; Inamori, Y. Biological activity of tropolone. Biol. Pharm. Bull. 2003, 26, 1487-1490. [CrossRef]

273. Morita, Y.; Matsumura, E.; Okabe, T.; Fukui, T.; Ohe, T.; Ishida, N.; Inamori, Y. Biological activity of $\beta$-dolabrin, $\gamma$-thujaplicin, and 4-acetyltropolone, hinokitiol-related compounds. Biol. Pharm. Bull. 2004, 27, 1666-1669. [CrossRef]

274. Yamato, M.; Ando, J.; Sakaki, K.; Hashigaki, K.; Wataya, Y.; Tsukagoshi, S.; Tashiro, T.; Tsuruo, T. Synthesis and antitumor activity of tropolone derivatives. 7. Bistropolones containing connecting methylene chains. J. Med. Chem. 1992, 35, 267-273. [CrossRef] [PubMed]

275. Inamori, Y.; Tsujibo, H.; Ohishi, H.; Ishii, F.; Mizugaki, M.; Aso, H.; Ishida, N. Cytotoxic effect of hinokitiol and tropolone on the growth of mammalian cells and on blastogenesis of mouse splenic T cells. Biol. Pharm. Bull. 1993, 16, 521-523. [CrossRef] [PubMed]

276. Yasumoto, E.; Nakano, K.; Nakayachi, T.; Morshed, S.R.; Hashimoto, K.; Kikuchi, H.; Nishikawa, H.; Kawase, M.; Sakagami, H. Cytotoxic activity of deferiprone, maltol and related hydroxyketones against human tumor cell lines. Anticancer Res. 2004, 24, 755-762. [PubMed]

277. Nagao, Y.; Sata, M. Effect of oral care gel on the quality of life for oral lichen planus in patients with chronic HCV infection. Virol. J. 2011, 8, 348. [CrossRef] [PubMed]

278. Doze, V.A.; Westphal, L.M.; White, P.F. Comparison of propofol with methohexital for outpatient anesthesia. Anesth. Analg. 1986, 65, 1189-1195. [CrossRef]

279. James, R.; Glen, J.B. Synthesis, biological evaluation, and preliminary structure-activity considerations of a series of alkylphenols as intravenous anesthetic agents. J. Med. Chem. 1980, 23, 1350-1357. [CrossRef]

280. Shafer, A.; Doze, V.A.; Shafer, S.L.; White, P.F. Pharmacokinetics and pharmacodynamics of propofol infusions during general anesthesia. Anesthesiology 1988, 69, 348-356. [CrossRef] 
281. Antkowiak, B.; Rammes, G. GABA(A) receptor-targeted drug development-New perspectives in perioperative anesthesia. Expert Opin. Drug Discov. 2019, 14, 683-699. [CrossRef]

282. Vasileiou, I.; Xanthos, T.; Koudouna, E.; Perrea, D.; Klonaris, C.; Katsargyris, A.; Papadimitriou, L. Propofol: A review of its non-anaesthetic effects. Eur. J. Pharmacol. 2009, 605, 1-8. [CrossRef]

283. Hanrahan, S.J.; Greger, B.; Parker, R.A.; Ogura, T.; Obara, S.; Egan, T.D.; House, P.A. The effects of propofol on local field potential spectra, action potential firing rate, and their temporal relationship in humans and felines. Front. Hum. Neurosci. 2013, 7, 136. [CrossRef]

284. Shi, Q.-Q.; Sun, X.; Fang, H. A mechanism study on propofol's action on middle latency auditory evoked potential by neurons in ventral partition of medial geniculate body in rats. Eur. Rev. Med. Pharmacol. Sci. 2014, 18, 1859-1868. [PubMed]

285. Kono, T.; Kanematsu, T.; Kitajima, M. Exodus of Kampo, traditional Japanese medicine, from the complementary and alternative medicines: Is it time yet? Surgery 2009, 146, 837-840. [CrossRef] [PubMed]

286. Hijikata, Y. Analgesic treatment with Kampo prescription. Expert Rev. Neurother. 2006, 6, 795-802. [CrossRef] [PubMed]

287. Mochiki, E.; Yanai, M.; Ohno, T.; Kuwano, H. The effect of traditional Japanese medicine (Kampo) on gastrointestinal function. Surg. Today 2010, 40, 1105-1111. [CrossRef]

288. Motoo, Y.; Arai, I.; Hyodo, I.; Tsutani, K. Current status of Kampo (Japanese herbal) medicines in Japanese clinical practice guidelines. Complement. Ther. Med. 2009, 17, 147-154. [CrossRef]

289. Wachtel-Galor, S.; Benzie, I.F.F. Herbal medicine: An introduction to its history, usage, regulation, current trends, and research needs. In Herbal Medicine: Biomolecular and Clinical Aspects, 2nd ed.; Benzie, I.F.F., Wachtel-Galor, S., Eds.; CRC Press: Boca Raton, FL, USA, 2011; Chapter 1.

290. Matsushita, A.; Fujita, T.; Ohtsubo, S.; Kumamoto, E. Traditional Japanese medicines inhibit compound action potentials in the frog sciatic nerve. J. Ethnopharmacol. 2016, 178, 272-280. [CrossRef]

291. Fink, B.R.; Cairns, A.M. Differential slowing and block of conduction by lidocaine in individual afferent myelinated and unmyelinated axons. Anesthesiology 1984, 60, 111-120. [CrossRef]

292. Brodin, P. Differential inhibition of A, B and C fibres in the rat vagus nerve by lidocaine, eugenol and formaldehyde. Arch. Oral Biol. 1985, 30, 477-480. [CrossRef]

293. Nakamura, M.; Jang, I.-S. Indomethacin inhibits tetrodotoxin-resistant $\mathrm{Na}^{+}$channels at acidic $\mathrm{pH}$ in rat nociceptive neurons. Neuropharmacology 2016, 105, 454-462. [CrossRef]

294. Joshi, S.K.; Mikusa, J.P.; Hernandez, G.; Baker, S.; Shieh, C.C.; Neelands, T.; Zhang, X.F.; Niforatos, W.; Kage, K.; Han, P.; et al. Involvement of the TTX-resistant sodium channel Nav 1.8 in inflammatory and neuropathic, but not post-operative, pain states. Pain 2006, 123, 75-82. [CrossRef] 